
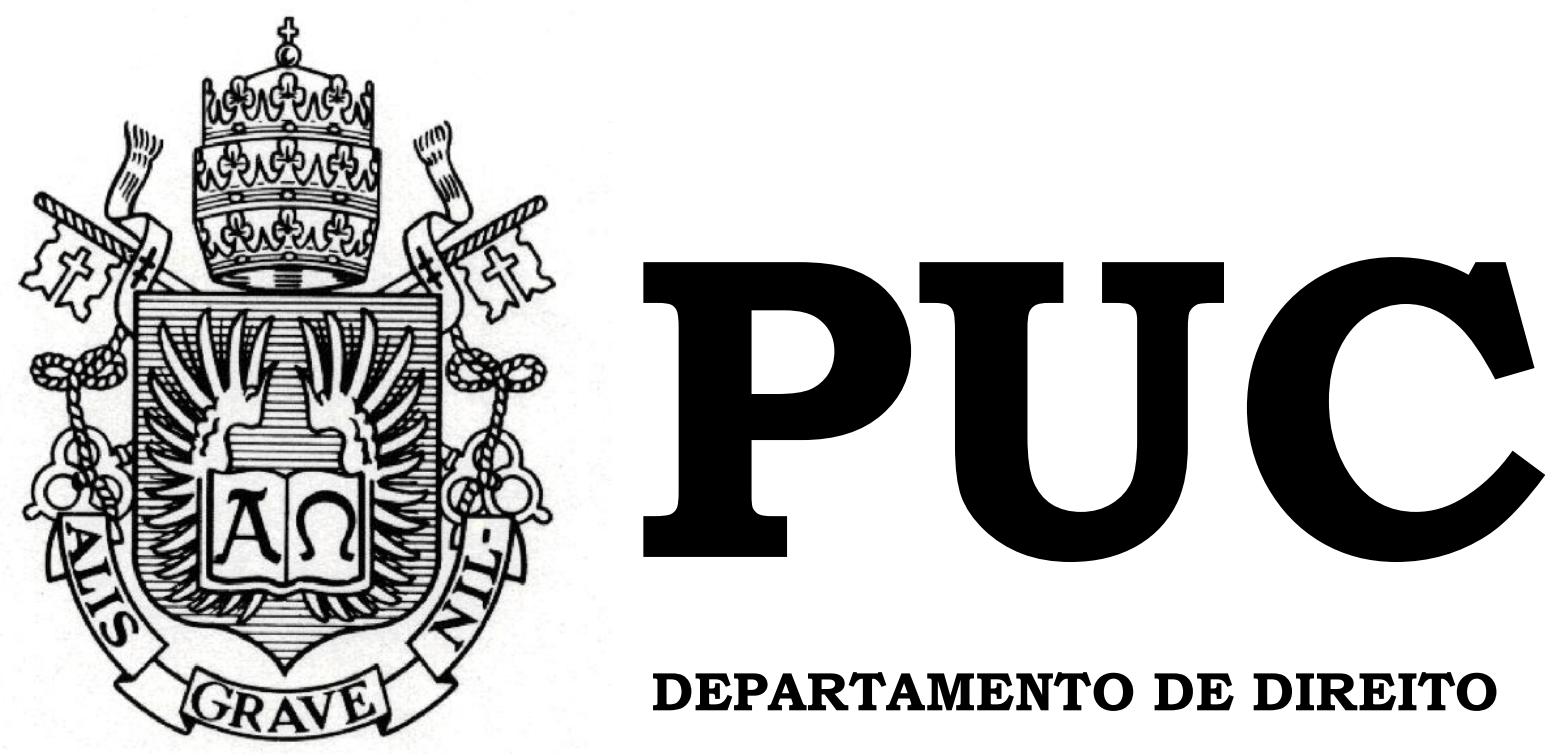

DEPARTAMENTO DE DIREITO

\title{
"O PRINCÍPIO DA INSIGNIFICÂNCIA E SUA APLICABILIDADE NO CRIME DE PECULATO SOB A ÓPTICA DO SUPREMO TRIBUNAL FEDERAL E SUPERIOR TRIBUNAL DE JUSTIÇA"
}

por

DAYENNE CARVALHO DA ROCHA

ORIENTADORA: Victória Sulocki

Coorientador: Breno Melaragno

2018.1

PONTIFÍCIA UNIVERSIDADE CATÓLICA DO RIO DE JANEIRO RUA MARQUÊS DE SÃO VICENTE, 225 - CEP 22453-900 RIO DE JANEIRO - BRASIL 


\section{O principio da insignificância e sua aplicabilidade no crime de peculato sob a óptica do Supremo Tribunal Federal e Superior Tribunal de Justiça}

por

Dayenne Carvalho da Rocha

Monografia apresentada ao Departamento de Direito da Pontificia Universidade Católica do Rio de Janeiro (PUC-Rio) para a obtenção do Título de Bacharel em Direito.

Orientadora: Victória Sulocki

Coorientador: Breno Melaragno 
Dedico o presente trabalho a minha mãe, ao meu pai e a minha avó, por sempre me apoiarem, e me incentivarem a realizar os meus sonhos. 


\section{AGRADECIMENTOS}

Disse, há algum tempo, que não tinha a intenção de fazer nenhum agradecimento. Apesar de a primeira vista demonstrar ingratidão, esse pensamento significa o reconhecimento de minha inabilidade em fazê-lo de maneira suficiente. Não tenho palavras para expressar o apoio e compreensão das pessoas que mais estiveram presentes nesse momento, e parece-me que nada do que diga estará a altura para retribuí-los.

Agradeço à minha mãe, Claudia, pelos debates acerca do tema, mas principalmente por suportar o meu mau humor e me dar todo o apoio necessário. Por estar presente durante toda a minha formação e por sempre ter me incentivado a dar o meu melhor. Obrigada por ser exatamente assim.

Ao meu pai, Marcos, pelas palavras de apoio em meio aos meus surtos de ansiedade e por entender a minha ausência em diversos momentos, principalmente nessa etapa final. Obrigada por ser sempre incrível comigo!

Ao professor Breno Melaragno, que me auxiliou na elaboração do presente trabalho. Agradeço, também, pelas lições em sala de aula. Sua paixão pela advocacia criminal são evidentes, e me serviram de grande inspiração.

Ao meu amor, Joaquim, que teve toda paciência do mundo comigo, principalmente nesse último semestre, que me deu forças e facilitou minha vida sempre que possível.

À minha irmã de alma Karla, mais do que agradecer por todo e apoio e carinho recebidos. Por sempre estar presente e me ajudando nos momentos mais difíceis da minha vida! Obrigada pelas revisões realizadas neste trabalho, muito obrigada! Você foi fundamental nessa etapa final, e sempre fez tudo com muito carinho!

À minha avó, mais do que agradecer, eu quero dedicar este trabalho e toda a minha formação. Não seria metade do que sou hoje sem suas lições, 
de vida. Obrigada pela convivência, pela criação, por ser tudo que é para mim. À senhora, realmente, me faltam palavras. Devo apenas repetir, infinitamente, muito obrigada. 


\section{RESUMO}

ROCHA, Dayenne Carvalho da. O Princípio Da Insignificância e sua aplicabilidade no crime de peculato sob a óptica do Supremo Tribunal Federal e Superior Tribunal de Justiça (Monografia/ Graduação em Direito) - Pontifícia Universidade Católica do Rio de Janeiro, Rio de Janeiro, 2018.

O presente trabalho abarca proposições acerca da possibilidade de aplicação do Princípio da Insignificância como mecanismo de política criminal de descriminalização em relação ao crime de peculato sob a perspectiva de um modelo normativo garantista baseado em um direito penal mínimo. Destarte, a metodologia utilizada abrange pesquisa doutrinária e jurisprudencial. $\mathrm{O}$ referido tema ainda se mostra muito controvertido nos Tribunais brasileiros, em decorrência da ausência normativa para aplicação de tal princípio. Verifica-se na jurisprudência e doutrina controvérsia quanto à sua aplicação, especialmente tratando-se de Crimes Contra a Administração Pública. Especificamente com relação ao crime de peculato, parte da doutrina e jurisprudência atual, entende que tal princípio pode ser aplicado, apenas salientando que a conduta deverá carecer de tipicidade material, observandose alguns critérios objetivos. Existe outra parte, no entanto, que não o aplica, defendendo a tese que o tipo penal visa primordialmente tutelar à moralidade pública e secundariamente o patrimônio, não havendo que se falar em insignificância. Com base na evolução histórica e principiológica do sistema penal pátrio, nos posicionamentos doutrinários e nos entendimentos firmados no âmbito do entendimentos do Superior Tribunal de Justiça e Supremo Tribunal Federal, será feita uma análise concreta quanto a possibilidade de aplicação do aludido princípio aos crimes de peculato.

Palavras-Chave:

Princípios; Princípio da insignificância; Direito Penal; Crime de Peculato; Superior Tribunal de Justiça; Supremo Tribunal Federal. 


\section{SUMÁRIO}

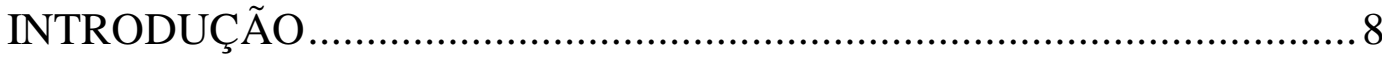

CAPITULO 1. PRINCÍPIO DA INSIGNIFICÂNCIA ................................ 12

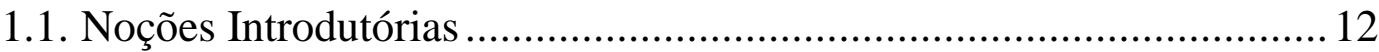

1.2. Breve Histórico do Princípio da Insignificância. ................................... 16

1.3. O Princípio da Insignificância no Direito Penal

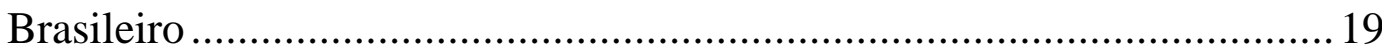

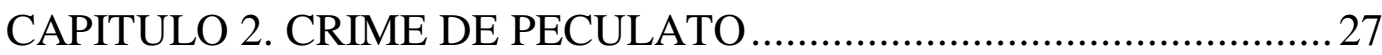

2.1. Dos Crimes Contra a Administração Pública.......................................2

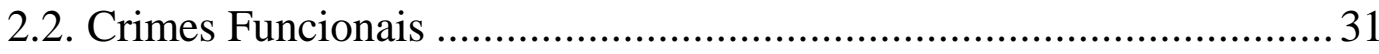

2.3. Breve Histórico do Crime de Peculato.................................................... 32

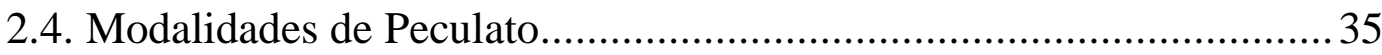

CAPITULO 3 - APLICAÇÂO DO PRINCÍPIO DA

INSIGNIFICÂNCIA AO CRIME DE PECULATO NA

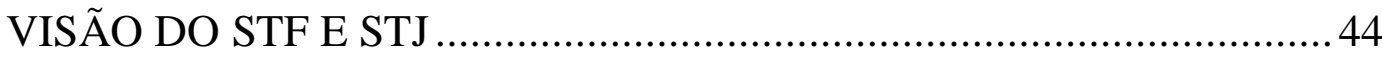

3.1. Decisões Proferidas Pelo Supremo Tribunal

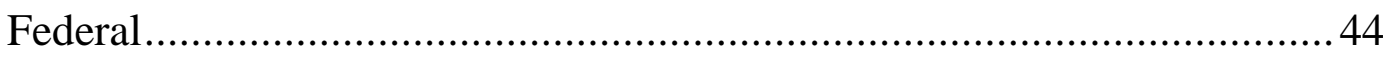

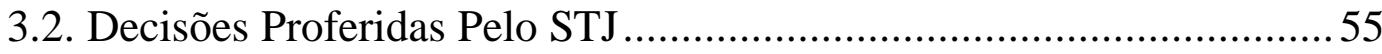

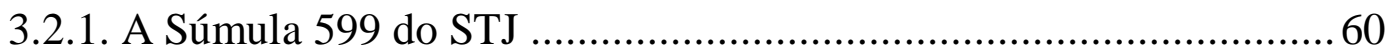

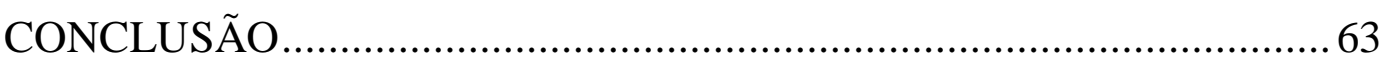

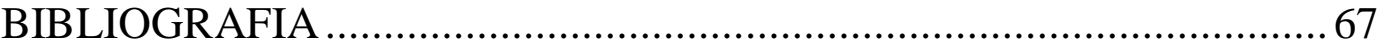




\section{ABREVIATURAS}

AgRg - Agravo Regimental

APL- Apelação

AREsp - Agravo em Recurso Especial

ART. - Artigo

DES. - Desembargador

HC - Habeas Corpus

Inq - Inquérito

MIN. - Ministro

$\mathrm{N}^{\mathrm{o}}$ - Número

REL.- Relator

Resp - Recurso Especial

STF - Supremo Tribunal Federal

STJ - Superior Tribunal de Justiça

STM - Superior Tribunal Militar

TJ - Tribunal de Justiça 


\section{INTRODUÇÃO}

A Constituição Federal de 1988 estabeleceu como um dos fundamentos do Estado Democrático de Direito a dignidade da pessoa humana em seu artigo $1^{\circ}$, inciso III. Dessa premissa irradiam diversos direitos fundamentais, princípios e garantias constitucionais. Sobretudo, vigora uma conjuntura jurídica em que se estabelece só ser possível limitar certos direitos quando bens jurídicos fundamentais para a sociedade sofrerem significativa lesão ou ameaça de lesão - Princípio da Intervenção Mínima.

Em razão disso, e em decorrência do caráter punitivo que o Direito Penal possui, considera-se que este deve ser a ultima ratio, ou seja, o último remédio, só devendo atuar quando nenhuma outra esfera do direito for capaz e eficiente para efetuar o controle social, não sendo possível que seja o único instrumento para realização de tal controle. Isto é, o Direito Penal deve observar seu caráter fragmentário e subsidiário.

O princípio da insignificância surge como uma forma de restringir o poder punitivo estatal, e excluindo do seu alcance aquelas condutas que apesar de se subsumirem à tipicidade formal não ofendem de forma significativa os bens jurídicos tutelados pelo Direito Penal, e, portanto, carecem de tipicidade material. O referido instituto evita que o sistema se infle de condutas irrelevantes do ponto de vista penal, cuja persecução e punição trariam uma indesejável hipertrofia penal e consequentemente a banalização dessa importante esfera jurídica.

Por sua vez, o crime de peculato, em suas modalidades mais recorrentes, assemelha-se ao furto e a apropriação indébita, porém, possui como sujeito ativo da ação necessariamente um funcionário público, nos moldes do artigo 327 do Código Penal ${ }^{1}$, por conseguinte trata-se de crime

\footnotetext{
1 “Art. 327 - Considera-se funcionário público, para os efeitos penais, quem, embora transitoriamente ou sem remuneração, exerce cargo, emprego ou função pública.

$\S 1^{\circ}$ - Equipara-se a funcionário público quem exerce cargo, emprego ou função em entidade paraestatal, e quem trabalha para empresa prestadora de serviço contratada ou conveniada para a
} 
funcional. $\mathrm{O}$ bem jurídico tutelado nesse tipo penal é a Administração Pública, tanto sob seu caráter patrimonial, quanto sob seu caráter moral.

O estudo do princípio da insignificância mostra-se de suma importância, considerando o fato do mesmo não possuir previsão legal, especialmente no que tange à sua aplicabilidade aos crimes de peculato, que em muitos casos envolvem um bem material de valor ínfimo, mas tem a aplicação da bagatela afastada por entender-se que o dano à moralidade administrativa não pode ser quantificado. Os que adotam essa corrente sustentam que a conduta não pode ser considerada minimamente ofensiva, nem que há ausência de periculosidade na ação, sendo de alto grau de reprovabilidade, neste sentido se posiciona o STJ.

A título de exemplo, o funcionário público que se apropria indevidamente de uma resma de papel, aproveitando-se de sua função, estaria incurso no crime de peculato-apropriação, descrito no artigo 312, Caput, do Código Penal. Em que pese o valor ínfimo do bem material indevidamente apropriado, para os que sustentam ser impossível atribuir à esta conduta inexpressiva ofensividade, não seria possível aplicar o princípio da bagatela.

Por outro lado, há quem defenda a possibilidade de se aplicar ao crime de peculato o princípio da insignificância, alguns fundamentam esse posicionamento afirmando que diante do valor ínfimo do bem material apropriado indevidamente, a Administração Pública sequer sofreria algum dano, dando maior relevo ao aspecto patrimonial do bem jurídico tutelado. Também há aqueles que além de fazer considerações acerca do valor ínfimo, ponderam que o próprio Estado tipifica alguns valores como ínfimos e atribui caráter insignificante a algumas condutas, fazendo um paralelo com o crime de Descaminho (artigo 334 do Código Penal²).

execução de atividade típica da Administração Pública.

$\S 2^{\circ}$ - A pena será aumentada da terça parte quando os autores dos crimes previstos neste Capítulo forem ocupantes de cargos em comissão ou de função de direção ou assessoramento de órgão da administração direta, sociedade de economia mista, empresa pública ou fundação instituída pelo poder público"

2 "Art. 334. Iludir, no todo ou em parte, o pagamento de direito ou imposto devido pela entrada, pela saída Art. 334. Iludir, no todo ou em parte, o pagamento de direito ou imposto devido pela 
Em que pese o STJ ter sumulado seu entendimento, as controvérsias acerca do tema nos tribunais e juízos a quo ainda são muitas. Ademais, o STF não possui uma jurisprudência sedimentada sobre o assunto, sendo possível encontrar julgados aplicando o princípio da insignificância ao crime de peculato e outros rechaçando-o.

O presente trabalho se propõe a análise da aplicabilidade do princípio da insignificância ao crime de peculato sob a óptica das duas principais Cortes do país, o Superior Tribunal de Justiça e o Supremo Tribunal Federal. Para tanto, far-se-á a análise dos fundamentos e requisitos exigidos nas decisões proferidas por ambos os Tribunais para aplicação ou não o referido instituto.

Para isso, entendeu-se por bem realizar a divisão desse trabalho em quatro etapas. Primeiro, realizar-se-á uma completa análise do Princípio da Insignificância, apresentando seu histórico de forma a elucidar como se introduziu no direito penal brasileiro. Serão trazidos conceito, natureza jurídica e seu fundamento. Ademais, também será apresentado como se dá a aplicação do referido princípio de uma maneira geral pelo STJ e STF.

Em um segundo momento, buscaremos apresentar os conceitos de administração pública, funcionário público, e crimes funcionais, fundamentais para a compreensão do crime de peculato. Optou-se por esmiuçar o delito de peculato, considerando seus aspectos estruturais, conceito e espécies.

$\mathrm{Na}$ terceira parte, versaremos especificamente sobre a aplicação do Princípio da Insignificância ao crime de Peculato, considerando para tal os julgamentos proferidos pela mais alta Corte do país, o Supremo Tribunal Federal, apresentando os requisitos empregados para o reconhecimento e aplicação de tal princípio a casos concretos. Em seguida, serão apresentados os fundamentos empregados pelo STJ para rechaçar a aplicação do princípio da bagatela, através da análise de julgados que ensejaram a edição da Súmula 
599 do STJ.

Finalmente, na quarta parte se ostentará a conclusão, examinando de maneira eficaz a oportunidade ou não do reconhecimento e aplicabilidade do princípio da insignificância ao delito de peculato. 


\section{CAPITULO 1. PRINCÍPIO DA INSIGNIFICÂNCIA}

\subsection{Noções Introdutórias}

A palavra "princípio" tem raízes do latim "principium", e significa, superficialmente, início, começo, origem das coisas, gênese. Apesar de não haver um dispositivo legal que positive o seu conceito jurídico, há muitos estudiosos e doutrinadores que se debruçam sobre o tema e nos permitem em uma análise ampla traçar elementos que tornem possível a sua acepção judiciária que guarda identidade com a definição do mundo não jurídico.

De acordo com esses, tratam-se de enunciações basilares que deverão inspirar e direcionar todo o ordenamento jurídico, premissas que condicionam as estruturas subsequentes. São o esteio, o alicerce, o suporte, do sistema jurídico. Encerram valores fundamentais que representam a estrutura ideológica e refletem os valores de uma dada sociedade. Conforme assevera Robert $\mathrm{Alexy}^{3}$, são verdadeiros mandamentos de otimização, servindo como fonte de interpretação e integração do Direito Positivo, cuja aplicação deve ser feita na maior e melhor proporção possível dentro da possibilidade real e jurídica em questão, ou seja, podem ser cumpridos em diferentes graus.

Maurício Ribeiro Lopes se posiciona acerca dos princípios da seguinte forma:

"O que define algo como princípio é precisamente sua capacidade de superar os limites da sua força interna para irradiar comandos operadores do funcionamento de estruturas alheias ao próprio ser. O princípio projeta sua relevância sobre a existência de outros seres, por isso seu caráter transcendental, superior e vinculante."

Os princípios instruirão a atividade legislativa na criação de novas normas, ao mesmo tempo que guiarão e servirão o judiciário na interpretação

\footnotetext{
${ }^{3}$ ALEXY, Robert. Teoria dos Direitos Fundamentais. Tradução de Virgílio Afonso da Silva. 2. ed. São Paulo: Malheiros, 2011, p.86.

${ }^{4}$ LOPES, Mauricio Antonio Ribeiro. Princípio da insignificância no direito penal. 2 ed. São Paulo: Revista dos Tribunais, 2000. p. 31.
} 
dessas, sendo também instrumento orientador em sua aplicação, buscando a integração do ordenamento jurídico, como leciona Miguel Reale ${ }^{5}$ Logo, observa-se que eles permeiam toda a cadeia normativa, fazendo-se incidir em todas as etapas, desde a criação até a aplicação, sendo normas finalísticas.

No pós positivismo jurídico, abandona-se a ideia de que os princípios possuem um caráter meramente programático, de simples orientações. Passam, então, a ter um caráter normativo, ou seja, ser reconhecidos como normas e afirma-se a aplicação direta e imediata. Portanto, em decorrência dessa evolução, no neoconstitucionalismo o entendimento atual é de que a norma é gênero, do qual são espécies os princípios e as regras.

Mostra-se oportuno pontuar o que difere os princípios das regras, sendo certo que os primeiros possuem um sentido amplo, um elevado grau de abstração e generalidade, consequentemente, com uma grande margem de aplicabilidade. Quando um princípio entra em colisão com outro, ambos subsistem, uma vez que sua incidência deve se dar no maior grau possível, além do interprete ter mais liberdade no momento de sua aplicação, pois precisa-se de um análise subjetiva.

Por sua vez, as regras possuem um caráter mais específico, sua incidência se restringe a situações determinadas, não sendo possível uma coexistir com outra oposta. Sua aplicabilidade se dá ao modo tudo ou nada, consoante Dworkin ${ }^{6}$, de modo que o intérprete possui menos flexibilidade por conta de sua objetividade.

Pode-se afirmar que no Direito existem três tipos de princípios, os princípios gerais, os princípios constitucionais e os infraconstitucionais. Quanto ao primeiro tipo, doutrinadores como Paulo Bonavides ${ }^{7}$ e Lenio Streck $^{8}$ defendem sua existência. Segundo este último, não existiria um

\footnotetext{
${ }^{5}$ REALE, Miguel. Lições Preliminares de Direito. $27^{\mathrm{a}}$ ed. São Paulo: Saraiva, 2003, p 37.

${ }^{6}$ DWORKIN, Ronald. Levando os direitos a sério. Tradução de Nelson Boeira. São Paulo: Martins Fontes, 2002, p. 39.

${ }^{7}$ BONAVIDES, Paulo. Curso de Direito Constitucional. $7^{\mathrm{a}}$ ed. São Paulo: Malheiros. 1997. p. 228

${ }^{8}$ STRECK, Lenio Luiz. Hermenêutica Jurídica e $(m)$ crise. $5^{\text {a }}$ ed., Porto Alegre: Livraria do Advogado, 2004. p. 108.
} 
conceito definido de princípios gerais, sendo certo que corresponderiam as normas de Direito Natural, e "adquirem um significado apenas quando considerados em conjunto com o restante do sistema jurídico: daí a necessidade de se pressupô-lo como uma totalidade". O segundo tipo diz respeito aos princípios presentes na Constituição, explícitos e implícitos, que buscam resguardar os direitos fundamentais. Por fim, os princípios infraconstitucionais são os positivados na legislação infraconstitucional.

A prevalência de um princípio constitucional (seja ele implícito ou explícito) sob o outro princípio constitucional dependerá do caso concreto, não sendo possível, para a maioria da doutrina, que haja hierarquia entre eles, em uma situação um princípio poderá prevalecer sob outro e em outra poderá se dar de forma oposta. Sendo assim, deve-se resolver a colisão através da ponderação, observando-se o Princípio da Proporcionalidade e Razoabilidade, não havendo princípio absoluto, conforme ensina Robert Alexy ${ }^{9}$.

Entretanto, considerando-se que no Brasil o modelo de Hans Kelsen ${ }^{10}$ foi o adotado para organizar as normas, no qual estas possuem seu fundamento de validade na validade de outra norma superior, de forma que estão distribuídas como se estivessem em uma pirâmide, e, observando-se ainda que os princípios são normas, alguns doutrinadores entendem que há hierarquia entre os princípios. Neste sentido, Geraldo Ataliba, assevera que:

"O sistema jurídico se estabelece mediante uma hierarquia segundo a qual algumas normas descansam em outras, as quais, por sua vez, repousam em princípios que, de seu lado, se assentam em outros princípios mais importantes. Dessa hierarquia decorre que os princípios maiores fixam as diretrizes gerais do sistema e subordinam os princípios menores. Estes subordinam certas regras que, à sua vez, submetem outras (...)"11.

A ideia de hierarquia entre princípios, quando se dá entre princípios constitucionais e princípios infraconstitucionais, parece simples e sem muitas

\footnotetext{
${ }^{9}$ ALEXY, Robert. Teoria dos Direitos Fundamentais. Tradução de Virgílio Afonso da Silva. 2. ed. São Paulo: Malheiros, 2011, p.90.

${ }^{10}$ KELSEN, Hans. Teoria pura do direito. 8. ed. São Paulo: WMF; M. Fontes, 2009. P. 215.

${ }^{11}$ ESPÍNDOLA, Ruy Samuel. Conceito de Princípios Constitucionais. Revista dos Tribunais, São Paulo, 1999, p. 165.
} 
controvérsias, já que existe dentro do próprio sistema jurídico uma hierarquia. Porém, quando a disputa se dá entre os princípios constitucionais de forma isolada é que se acentua a discussão doutrinária.

No que tange à colisão entre os princípios e as regras, considerando o caráter direcionador e transcendental dos princípios, acredita-se que estes devem prevalecer, sendo certo que feri-los significaria ferir a própria constituição ou o ordenamento jurídico, a menos que uma regra tenha como objetivo proteger outro princípio constitucional, de modo que indiretamente estaríamos diante de uma colisão de princípios. Podemos citar, ainda, a lição de Eros Grau:

“[...] é preciso anotar, que as regras são concreções dos princípios; são especificações regulatórias desses; são desdobramentos normativos dos mesmos. Assim, cumpre observar que não se manifestam antinomias, conflitos, colidências entre princípios e regras. Desta forma, quando em confronto dois princípios, um prevalece sobre o outro, e as regras que dão concreção ao que foi desprezado são afastadas, e essas não se aplicaram a determinada hipótese, ainda que permaneçam integradas, validamente, no ordenamento jurídico." 12

No campo do Direito Penal não é diferente, já que este também tem suas bases solidificadas nos princípios, sobretudo os constitucionais, que são meios através dos quais a Constituição impõe ao legislador a observância dos direitos e garantias fundamentais, orientando o Estado no exercício da aplicação da lei penal. São verdadeiros "pressupostos técnico-jurídicos que configuram a natureza, as características, os fundamentos, a aplicação e a execução do Direito Penal"13.

A Constituição traz muitos princípios direcionados ao Direito Penal, que tem como objetivo trazer limitações à atividade punitiva do Estado, além de serem importantes instrumentos de tutela dos bens que são fundamentais para atingir os fins sociais do mesmo, como afirma Luiz Luisi ${ }^{14}$.

Dentre os Princípios Penais, far-se-á a análise da aplicabilidade de um

\footnotetext{
${ }^{12}$ GRAU, Eros Roberto. A Ordem Econômica na Constituição de 1988 (Interpretação e Crítica). São Paulo: Revista dos Tribunais, 1990.

${ }^{13}$ PRADO, Luiz Regis. Curso de Direito Penal Brasileiro. $4^{\mathrm{a}}$ ed. São Paulo: Editora Revista dos Tribunais, 2010.p. 139

${ }^{14}$ LUISI, Luiz. Os princípios constitucionais penais. 2a. ed. Porto Alegre: Sérgio Antônio Fabris. 2003.
} 
dos mais relevantes princípios - o Princípio da Insignificância. Trata-se de verdadeiro instrumento de política criminal, utilizado como método de interpretação, com o fim de dar um tratamento mais justo, afastando condutas apenas formalmente típicas da incidência penal.

\subsection{Breve Histórico do Princípio da Insignificância.}

Não existe um entendimento pacífico acerca da origem do princípio da insignificância. Diversos autores, como Diomar Ackel Filho ${ }^{15}$, afirmam que sua origem se deu no Direito Romano, e assim o fazem devido ao brocardo minimis non curat praetor - o pretor não cuida de coisas pequenas.

No entanto, sob o argumento dessa máxima ser quase exclusivamente aplicada no Direito Civil, Maurício Antônio Ribeiro Lopes discorda desse entendimento:

"O Direito Romano foi notadamente desenvolvido sob a óptica do Direito Privado e não do Direito Público. Existe naquele brocardo menos do que um princípio, um mero aforismo. Não que não pudesse ser aplicado vez ou outra a situações de Direito Penal, mas qual era a noção que os romanos tinham do princípio da legalidade? Ao que me parece, se não nenhuma, uma, mas muito limitada, tanto que não se fez creditar aos romanos a herança de tal princípio." 16

Alguns autores pontuam que a origem e o desenvolvimento do princípio da insignificância estão ligados ao iluminismo, à busca por um Direito Penal de natureza humanística, eliminando crueldades que prevaleciam durante o Estado Absolutista, estabelecendo limites à intervenção do Estado nas liberdades individuais dos cidadãos, e consequentemente possuindo uma ligação com o desenvolvimento do princípio da legalidade.

O princípio da legalidade nasce junto a esse ideal iluminista, em 1762, Jean-Jacques Rousseau escreve a Teoria do Contrato Social ${ }^{17}$ em que fala da

\footnotetext{
${ }^{15}$ ACKEL FILHO, Diomar apud LOPES, Mauricio Antonio Ribeiro. Princípio da insignificância no direito penal. 2 ed. São Paulo: Revista dos Tribunais, 2000. p. 41

${ }^{16}$ LOPES, Mauricio Antonio Ribeiro. Princípio da insignificância no direito penal. 2 ed. São Paulo: Revista dos Tribunais, 2000. p. 42.

${ }^{17}$ ROUSSEAU, Jean-Jacques. Do Contrato Social. Tradução de Ricardo Rodrigues da Gama. $1^{\text {a }}$ ed.
} 
importância de se garantir a liberdade civil e a necessidade de se estabelecer leis para que o homem pudesse obtê-la. Em 1764, Cesare Bonesana, Marquês de Beccaria, em seu livro "Dos Delitos e Das Penas", afirma que "a exata medida dos crimes é o seu prejuízo à sociedade" 18 .

É possível observar alguns elementos que ensaiam o princípio da insignificância na Declaração dos Direitos do Homem de 1789, fruto da revolução francesa, por exemplo em seu artigo $5^{\circ}$ "A lei não proíbe senão as ações nocivas à sociedade. Tudo que não é vedado pela lei não pode ser obstado e ninguém pode ser constrangido a fazer o que ela não ordene." ${ }^{19}$.

Em razão do exposto, alguns autores vão dizer que o princípio da insignificância foi incorporado à Declaração supracitada, ocasião em que toma os moldes exigido pelo Direito Penal, sendo a Revolução Francesa peça fundamental para o marco histórico humanístico e formalístico dos princípios constitucionais que norteiam o direito contemporâneo, como dispõe Rogerio Greco $^{20}$.

Ivan Luiz Silva ${ }^{21}$ robustece o entendimento acima, afirmando que a Declaração Universal dos Direitos do Homem e do Cidadão é a maior explanação do Princípio da Legalidade na disposição jurídica ao tempo, sistematizado pelos pensamentos iluministas. Por conseguinte, é notável observar vestígios do Princípio da Insignificância na histórica Declaração já mencionada.

A expressão "crime de bagatela" remete ao período da Europa pós Guerra. O termo utilizado pelos alemães refere-se a pequenos delitos contra o patrimônio praticados no contexto Europeu vivenciado após as duas

\footnotetext{
São Paulo: Russel, 2006.

${ }^{18}$ BECCARIA, Cesar. Dos Delitos e Das Penas. Prefácio: René Ariel Dotti. Tradução e Notas: Alexis Augusto Couto de Brito. São Paulo: Quartier Latin, 2005. p. 63.

19 Universidade de São Paulo. Declaração dos Direitos do Homem. Disponível em <http://www.direitoshumanos.usp.br/index.php/Declara\%C3\%A7\%C3\%A3o-Universal-dosDireitos-Humanos/declaracao-universal-dos-direitos-humanos.html>. Acesso em 22 fev. 2018.

${ }^{20}$ GRECO, Rogério. Curso de direito penal - parte geral, v. I. $12^{\mathrm{a}}$ ed. Niterói: Impetus, 2010, p. 18

${ }^{21}$ SILVA, Ivan Luiz da. Princípio da Insignificância no Direito Penal. 2. ed. Curitiba: Juruá, 2011. p. 87.
} 
Grandes Guerras, que deixaram o continente em situação socioeconômica devastadora, com forte desemprego e alimentação escassa.

Em 1903, Fran Von Liszt, conforme pontua Ivan Luiz da Silva, afirmava que a "legislação faz da pena, como meio de luta, um emprego excessivo. Se deveria refletir se não mereceria ser restaurado o antigo minima non curat praetor [... $]^{\prime 22}$, sendo possível vislumbrar, desde essa época, alguns autores dispondo sobre a necessidade de se retomar essa máxima romana e lhe dar uma nova roupagem.

Foi em 1972, com a obra "Política Criminal y Sistema Del Derecho Penal" do alemão Claus Roxin, que para a maior parte dos estudiosos o princípio da insignificância foi incorporado ao Direito Penal. Ali postulou-se o reconhecimento da insignificância como excludente de tipicidade, com fundamento no famoso brocardo latino já mencionado. Luiz Flávio Gomes pontua a respeito:

"Se por um lado não se pode duvidar que é muito controvertida a origem histórica da teoria da insignificância, por outro, impõe-se sublinhar que o pensamento penal vem (há tempos) insistindo em sua recuperação (pelo menos desde o século XIX). São numerosos os autores que desde esse período a invocam e pedem sua restauração: assim Carrara, Von Liszt, Quintiliano Saldaña, Roxin, Baumann, Blasco e Fernández de Moreda, Soler, Zaffaroni etc. Nas últimas décadas destacase o trabalho de Roxin, surgido em 1964, que postulou o reconhecimento da insignificância como causa de exclusão da tipicidade penal." ${ }^{, 23}$

Em síntese, é possível concluir que o Princípio da insignificância tem suas origens remotas no Direito Romano, e com o passar dos anos evoluiu em conformidade com o Princípio da Legalidade. Todavia, seu reconhecimento e surgimento apenas se deu, de fato, no século $\mathrm{XX}$, mais exatamente nos idos de 1964, pelo jurista alemão Claus Roxin.

O Princípio da Insignificância só possui previsão legal no Brasil no Código Penal Militar, sendo uma construção doutrinária e jurisprudencial. A primeira vez que o Supremo aplicou o mesmo foi no RHC 668.691, no qual reconheceu a inexpressividade da lesão decorrente de um acidente de

\footnotetext{
${ }^{22}$ Ibid. p. 87

${ }^{23}$ GOMES, Luiz Flávio. Princípio da Insignificância e outras excludentes de tipicidade. 2 ed. atual. e ampl. São Paulo: Editora Revista dos Tribunais, 2010. p. 54-55.
} 
trânsito, tendo negado a instauração de ação penal ${ }^{24}$.

\subsection{O Princípio da Insignificância no Direito Penal Brasileiro}

A Constituição Federal de 1988 instaurou o Estado Democrático de Direito, que tem como principal fundamento a dignidade da pessoa humana, da qual decorrerem diversos mecanismos que visam garantir direitos fundamentais individuais e coletivos. Diferentemente do Estado de Direito, que já foi superado, o mero cumprimento das leis não satisfazem mais essa nova ordem jurídica.

Assim, o Sistema Penal deve estar em conformidade com essa lógica neoconstitucional, pós positivista, que consagra o garantismo penal, sendo este um instrumento de aferição de validade da intervenção estatal, que deve obedecer às diretrizes preestabelecidas pela Constituição, só sendo legítima quando observa os princípios constitucionais, direitos e garantias fundamentais. Busca-se um sistema de poder punitivo mínimo, que atue quando realmente necessário, em observância à sua função social.

É devido a essa lógica que o Direito Penal, diferentemente das outras esferas do direito, tem caráter fragmentário e subsidiário, sendo a ultima ratio, só devendo atuar quando as demais forem ineficazes e insuficientes, e quando se tratar da proteção dos bens jurídicos mais importantes do ordenamento. Os bem jurídicos penais, sendo bens jurídicos fundamentais, são aqueles selecionados pelo legislador como de maior valor para a sociedade, de acordo com a época e valores culturais, cuja proteção é essencial para a convivência pacífica dos indivíduos que a compõe.

Diante disso, diversamente de outros ramos do direito em que as

\footnotetext{
${ }^{24}$ LEAL JÚNIOR, Cândido Alfredo Silva. O princípio da insignificância nos crimes ambientais: a insignificância da insignificância atípica nos crimes contra o meio ambiente da Lei 9.605/98. Revista de Doutrina da $4^{\mathrm{a}}$ Região, Porto Alegre, n.17, abr. 2007. Disponível em: <http://www.revistadoutrina.trf4.jus.br/artigos/edicao017/Candido_Leal.htm>. Acesso em: $26 \mathrm{fev}$ 2018.
} 
sanções possuem caráter "primordialmente ressarcitório e reparatório" 25 , nesta, a sanção empregada consiste quase exclusivamente em uma pena, possui caráter retributivo e preventivo, frequentemente ligada a restrição da liberdade, a fim de garantir a segurança jurídica e evitar o caos social, razão de formação do Contrato Social.

Partindo dessa premissa, busca-se reduzir cada vez mais o espectro de proteção do Direito Penal, visando prevenir que o Estado atue de maneira desproporcional, punindo penalmente condutas socialmente irrelevantes. O Estado deverá descriminalizar condutas, que mesmo positivadas em nosso ordenamento, desmerecem a efetiva tutela penal, em virtude de sua completa irrelevância material ao bem jurídico tutelado.

Diante do exposto, tem-se o Princípio da Insignificância como sendo um balizador do Direito Penal, impedindo que o Estado abuse do seu jus puniendi de forma demasiada. Discorre sobre o tema Fernando Capez:

"O direito penal não cuida de bagatelas, nem admite tipos incriminadores que descrevam condutas incapazes de lesar o bem jurídico. Se a finalidade do tipo penal é tutelar bem jurídico, quando a lesão, de tão insignificante, torna-se imperceptível, não é possível proceder ao enquadramento, por absoluta falta de correspondência entre o fato narrado na lei e o comportamento iníquo realizado; os danos de nenhuma monta devem ser considerados fatos atípicos." 26

A fim de se entender melhor o princípio da insignificância, necessário se faz a análise do conceito analítico de crime, sendo primordial destacar que não existe um conceito exato previsto no Código Penal brasileiro, assim possuindo apenas conceitos eminentemente jurisprudenciais e doutrinários.

$\mathrm{Na}$ análise de diversas obras, como a dos autores Guilherme Souza $\mathrm{Nucci}^{27}$ e Rogerio Greco ${ }^{28}$, percebe-se que a teoria tripartida é a mais adotada. Aquele último afirma que um crime é composto por fato típico, ilícito e culpável e sem a incidência desses três requisitos não há crime. Um fato será

\footnotetext{
${ }^{25}$ ZAFFARONI, Eugenio Raúl. PIERANGELI, José Henrique. Manual de direito penal brasileiro: volume 1: parte geral. $9^{a}$ ed. rev. e atual. São Paulo: Editora Revista dos Tribunais, 2011

${ }^{26}$ CAPEZ, Fernando. Curso de Direito Penal - Parte Geral, artigos $1^{\circ}$ a $120^{\circ}$. São Paulo: Saraiva, v. 01,19 ed. 2015.p. 643.

${ }^{27}$ NUCCI, Guilherme de Souza. Código penal comentado. $6^{\mathrm{a}}$ ed. São Paulo: RT, 2006 p. 118.

${ }^{28}$ GRECO, Rogério. Curso de direito penal - parte geral, v. I. $12^{\mathrm{a}}$ ed. Niterói: Impetus, 2010.
} 
típico quando houver conduta e resultado, nexo de causalidade entre eles e tipicidade, dividindo-se este último em tipicidade formal e tipicidade material. A tipicidade formal se dá quando a prática delituosa se enquadra perfeitamente no tipo penal (subsunção formal) e a tipicidade material ocorre quando a lesão ou ameaça de lesão ao bem jurídico tutelado é intolerável e relevante, e consequentemente merece a tutela do Direito Penal.

Ao criar-se um tipo penal, busca-se restringir a sua incidência a um número determinado de situações, obedecendo ao princípio da legalidade. Ainda assim, a abstração que esses tipos trazem consigo faz com que seja possível que sua abrangência seja maior do que a desejável, e é em razão disso que faz-se necessário atribuir um caráter material e não meramente formal a eles. A respeito da tipicidade material expõe Carlos Vico Manãs ${ }^{29}$ :

"O juízo de tipicidade para que tenha efetiva significância e não atinja atos que devam ser estranhos ao Direito Penal, por sua aceitação pela sociedade ou dano social irrelevante deve entender o tipo na sua concepção material como algo dotado de conteúdo valorativo e não apenas sob seu aspecto normal de cunho eminentemente diretivo"

Nesse sentido, o princípio da insignificância vai atuar quando a conduta delituosa não apresentar relevância material, ainda que se amolde ao tipo formal, já que lesões ínfimas não possuem o condão de materializar o tipo penal, tendo natureza jurídica de excludente de tipicidade para maior parte da doutrina e jurisprudência. Sobre o tema, Rogério Greco leciona:

"Além da necessidade de existir um modelo abstrato que preveja com perfeição a
conduta praticada pelo agente, é preciso que, para que ocorra essa adequação, isto
é, para que a conduta do agente se amolde com perfeição ao tipo penal, seja levada
em consideração a relevância do bem que está sendo objeto de proteção. Quando o
legislador penal chamou a si a responsabilidade de tutelar determinados bens, como
a integridade física e o patrimônio, não quis abarcar toda e qualquer lesão corporal
sofrida pela vítima ou mesmo todo e qualquer tipo de patrimônio, não importando
o seu valor." 30 Alguns autores, como Abel Cornejo ${ }^{31}$, sustentam que a análise do grau de ofensividade ao bem jurídico e a relevância da conduta, deve ser feita na

\footnotetext{
${ }^{29}$ MANAS. Carlos Vico. O princípio da insignificância como excludente da tipicidade no Direito Penal. São Paulo: Saraiva. 1994. p. 53.

${ }^{30}$ GRECO, Rogério. Curso de direito penal - parte geral, v. I. $12^{\mathrm{a}}$ ed. Niterói: Impetus, 2010, p. 18.

${ }^{31}$ CORNEJO, Abel, apud, SILVA, Ivan Luis da. Princípio da insignificância no direito penal. 2. ed. Curitiba: Juruá, 2011, p. 167.
} 
antijuridicidade material, não devendo condicionar o tipo a nenhum critério valorativo, portanto para esses a natureza jurídica seria de excludente de antijuridicidade, ou seja, o fato não seria lesivo o suficiente para ser considerado ilícito.

O Eminente Ministro do STF, Celso de Mello, por ocasião do HC $84.412^{32}$ se posicionou acerca do assunto, filiando-se à corrente majoritária, assinalando que:

"o princípio da insignificância - que deve ser analisado em conexão com os postulados da fragmentariedade e da intervenção mínima do Estado em matéria penal - tem o sentido de excluir ou de afastar a própria tipicidade penal".

Apesar das controvérsias em relação à natureza e em que momento o princípio em comento incidirá, não resta dúvida que a ação do agente não pode ser um mero descumprimento de dever, precisa ter o poder de ofender o bem jurídico, que por sua vez precisa ter valor suficiente para ser tutelado pelas normas penais.

Atribuir a um bem a característica de insignificante ou de bagatela significa dizer que possui valor ínfimo, portanto, ainda que possa ser considerado um bem jurídico, não estaria enquadrado como bem jurídico penal, logo, não merece a tutela do Direito Penal, não estando impedido de receber a devida tutela em outras esferas do direito.

Vale ressaltar que não se confunde bem de valor ínfimo com bem de pequeno valor, uma vez que este pode ser apenado de uma forma mais branda, como o furto privilegiado, mas ainda assim trata-se de conduta típica e aquele exclui a tipicidade devido à mínima a ausência de lesão ao bem jurídico. Nesse sentido tem entendido o STJ, pontuando que:

"não se pode confundir bem de pequeno valor com o de valor insignificante ou irrisório, já que para aquela primeira situação existe o privilégio insculpido no $\S 2^{\circ}$ do artigo 155 do Código Penal" 33

\footnotetext{
${ }^{32}$ STF, HC 84412/ SP, Ministro Celso de Mello. Brasília. Data de Julgamento: 29/06/2004. Reiterado em diversos outros julgados como: STF, HC 123223/ MG, Ministro Teori Zavascki. Brasília. Data de Julgamento: 01/008/2014; STJ, REsp 1471784/ MG, Ministro Rogerio Schietti Cruz. Brasília. Data de Julgamento: 06/04/2015

${ }^{33}$ STJ, AgRg no REsp 1673946 SP, Ministro Jorge Mussi, Quinta Turma, Data de Julgamento: 07/11/2017.
} 
A referida Corte Superior fixou como valor ínfimo aqueles bens que não superam $10 \%$ do salário mínimo vigente à época do fato, e bem de pequeno valor aquele inferior ao salário mínimo ao tempo do fato, conforme HC 409041/SP ${ }^{34}$ e HC 424745/SP ${ }^{35}$.

Certo é que o princípio da insignificância não se aplica apenas a bens suscetíveis de valor pecuniário, mas também a outros disponíveis, como nos casos de lesão corporal leve, sendo nestes casos mais difícil de delinear parâmetros objetivos.

Há quem diferencie, ainda que a doutrina majoritária os veja como sinônimos, os crimes de bagatela do princípio da insignificância, como Maurício Ribeiro Lopes ${ }^{36}$, que afirma tratar-se o primeiro caso de uma prática delituosa que permite um modelo processual mais célere, o perdão judicial, assim como condiciona iniciativa da ação penal à vítima, não podendo a conduta ser considerada insignificante. Já o segundo é exemplo de conduta tipicamente formal, mas que não traz lesão e nem ameaça de lesão relevante ao bem jurídico, sendo portanto, atípica.

Por sua vez, o princípio da adequação social, que pressupõe uma conduta aceita pela sociedade por uma questão cultural, costumeira, não se confunde com o princípio da insignificância, que pressupõe uma ação que não apresenta relevante lesão ou ameaça de lesão ao bem jurídico. Nas palavras de Maurício Ribeiro Lopes “A Teoria da adequação social está prevalentemente regulada sobre o desvalor da ação e o princípio da insignificância sobre o desvalor do resultado." 37

Não se deve confundir também o princípio objeto de estudo do presente trabalho com o princípio da irrelevância penal do fato, consagrado pelo artigo 59 do Código Penal:

\footnotetext{
34 STJ, HC 409041/ SP, Ministro Joel Ilan Paciornik, Quinta Turma, Data de Julgamento: $07 / 12 / 2017$.

${ }^{35}$ STJ, HC 424745/ SP, Ministro Ribeiro Dantas, Quinta Turma, Data de Julgamento: 15/03/2018.

${ }^{36}$ LOPES, Mauricio Antonio Ribeiro. Princípio da insignificância no direito penal. 2 ed. São Paulo: Revista dos Tribunais, 2000.

37 Ibid
} 
"O juiz atendendo à culpabilidade, aos antecedentes, à conduta social, à personalidade do agente, aos motivos, às circunstâncias e conseqüências do crime, bem como ao comportamento da vítima, estabelecerá conforme seja necessário e suficiente para reprovação e prevenção do crime." 38 (Grifei)

Sendo certo que em um caso a conduta por não apresentar ofensa relevante, não atingir o bem de maneira significativa, será fato atípico, estando na esfera da teoria do delito a sua incidência. Enquanto no outro caso trata-se de conduta que apresenta lesão significativa para o Direito Penal, tratando-se de fato típico, no entanto, baseando-se no desvalor da conduta, do resultado e da culpabilidade, devendo todas as circunstâncias judiciais serem positivas ao indivíduo (personalidade, conduta social, antecedentes, motivos do crime, dentre outras), o julgador poderá entender pela não aplicação da pena.

Apesar de parecer clara a diferença entre esses dois princípios, não é o que se observa na jurisprudência. É muito comum a condensação de ambos e a exigência de requisitos subjetivos, ligados à culpabilidade, como a exigência da primariedade, para a aplicação do princípio da insignificância. Neste sentido tem entendido o STJ, conforme julgamento de AgRg no AREsp $1089134^{39}$.

Levando-se em consideração que o princípio da insignificância não possui uma previsão legal, a maior dificuldade é estabelecer critérios e limites para sua incidência. A fim de diminuir casuísmos o STF buscou fixar alguns parâmetros para aplicabilidade do mesmo.

Em relação a reincidência, no julgamento conjunto dos HC $123.108^{40}$, $123.533^{41}$ e $123.734^{42}$, tendo como relator o Eminente Ministro Roberto Barroso, ficou decidido que se a coisa subtraída é de valor ínfimo, (I) a

\footnotetext{
${ }^{38}$ BRASIL. Decreto-lei no 2.848, de 7 de dezembro de 1940. Código Penal. Rio de Janeiro, RJ, Dez, 1940.

${ }^{39}$ STJ, AgRg no AREsp: 1089134 /MG 2017/0100023-3, Ministro Relator Joel Ilan Paciornik, Quinta Turma, Data de Julgamento: 08/08/2017.

40 STF, HC 123108 / MG, Ministro Relator Roberto Barroso, Brasília, Data de Julgamento: $03 / 08 / 2015$.

${ }^{41}$ STF, HC 123533 / SP, Ministro Relator Roberto Barroso, Brasília, Data de Julgamento: $03 / 08 / 2017$.

${ }^{42}$ STF, HC 123734 / MG, Ministro Relator Roberto Barroso, Brasília, Data de Julgamento: 03/08/2015.
} 
reincidência, a reiteração delitiva e a presença das qualificadoras do art. 155, $\S 4^{\circ}$, devem ser levadas em consideração, podendo acarretar o afastamento da aplicação da insignificância; e (II) nenhuma dessas circunstâncias determina, por si só, o afastamento da insignificância, cabendo ao juiz analisar se a aplicação de pena é necessária. Além disso, conclui-se que, (III) uma vez aplicada pena privativa de liberdade inferior a quatro anos de reclusão ao reincidente, o juiz pode, se considerar suficiente, aplicar o regime inicial aberto, afastando a incidência do art. 33, § $2^{\circ}$, c, do Código Penal.

Portanto, o STF não estabeleceu a primariedade como requisito imprescindível à aplicação do princípio da bagatela, mas esse deve ser analisada junto às circunstâncias do caso concreto. Também fixou entendimento no sentido de que, para que o aplicador do direito possa reconhecer a insignificância de determinada conduta, faz-se necessário a presença de alguns requisitos, sendo eles a: (I) mínima ofensividade da conduta do agente, (II) nenhuma periculosidade social da ação, (III) reduzidíssimo grau de reprovabilidade do comportamento e (IV) inexpressividade da lesão jurídica provocada. Neste sentido HC $137.422^{43}$.

A "mínima ofensividade da conduta do agente" incumbe em uma análise sobre a ação, e a resposta que se quer buscar aqui é se esta possui a capacidade de lesionar o bem jurídico penal tutelado. Percebe-se uma ligação em relação ao princípio da lesividade, segundo o qual onde não há lesão ou perigo de lesão, não há crime (nullum crimen sine iniuria).

No que diz respeito à "inexistência de periculosidade social”, o que se deve levar em consideração é se o caráter de eficácia do Direito Penal em relação ao seu dever de manter ordem e a paz social está ameaçado de algum modo, já que um dos seus objetivos é a prevenção geral positiva, inibindo a sociedade a agir como o delinquente.

Em relação ao "reduzidíssimo grau de reprovabilidade do

\footnotetext{
${ }^{43}$ STF, HC 137422/SC, Ministro Relator Ricardo Lewandowski, Brasília, Data de Julgamento: 28/03/2017.
} 
comportamento", o que se avalia é se essa conduta é reprovada em larga escala, sendo um critério que deixa ampla margem de interpretação, difícil de dar-lhe um caráter que não seja subjetivo.

Por fim, quando se fala de "inexpressividade da lesão jurídica provocada", o que se tem em foco é o resultado, ou seja, se houve lesão ao bem jurídico penal tutelado e se essa lesão foi significativa. Por exemplo, no caso de um indivíduo subtrair um lápis de uma papelaria, de fato o bem material foi afanado, mas a conduta foi incapaz de ofender o bem jurídico penal tutelado, significativamente, não sendo plausível dizer que tenha o patrimônio sido afetado.

Incidem muitas críticas em relação aos requisitos citados, que afirmam serem de extrema redundância, sendo aplicados, em muitos casos, sem a devida reflexão. Paulo Queiroz dispõe sobre o tema:

"Parece-nos, porém, que tais requisitos são tautológicos. Sim, porque se mínima é a ofensa, então a ação não é socialmente perigosa; se a ofensa é mínima e ação não perigosa, em consequência, mínima ou nenhuma é a reprovação; e pois, inexpressiva a lesão jurídica. Enfim, os supostos requisitos apenas repetem a mesma ideia por meio de palavras diferentes, argumentando em círculo." 44

Muitos afirmam que os requisitos, apontados como objetivos pelo STF, possuem um caráter altamente subjetivo, e a controvérsia é muito grande quanto à aplicabilidade do princípio da insignificância: "deve-se ou não considerar elementos subjetivos?”, “quais bens podem ser atrelados à valor ínfimo?”, “Como lidar com relação àqueles bens que não possuem um valor pecuniário?”, “Sob quais crimes poderia recair?”, dentre outras questões.

Apesar de todas as incongruências e dificuldades, indiscutível é a importância desse princípio como método de política criminal, na medida em que funciona como vetor interpretativo restritivo do tipo penal, objetivando manter o Direito Penal dentro da sua função social, em consonância com os ditames constitucionais.

\footnotetext{
44 QUEIROZ, Paulo. Princípio da Insignificância. Disponível em < http://www.pauloqueiroz.net/476/>. Acesso em 22 fev. 2018.
} 


\section{CAPITULO 2. CRIME DE PECULATO}

\subsection{Dos Crimes Contra a Administração Pública}

Considerando que o delito objeto do presente estudo é perpetrado em face da Administração Pública, entende-se fundamental esmiuçar este conceito.

Administrar significa gerir algo, gerenciar negócios, pessoas, bens ou recursos, a fim de atingir objetivos. Pode-se dizer, em uma visão simples, que Administração Pública é um grande organismo, compreendendo um conjunto de órgãos, serviços e agentes do Estado, que gerem bens e interesses de extrema importância para a sociedade e visam satisfazer o pleno exercício dos direitos básicos dos cidadãos, tais como cultura, educação, saúde e segurança.

Nas palavras de Diógenes Gasparini "É encargo de guarda, conservação e aprimoramento dos bens, interesses e serviços da coletividade, que se desenvolve segundo a lei e a moralidade administrativa"45.

Há autores que a definem em dois sentidos, formal e material. Conforme, ensina Hely Lopes Meirelles:

"Em sentido formal, é o conjunto de órgãos instituídos para consecução dos objetivos do governo; em sentido material, é o conjunto das funções necessárias aos serviços públicos em geral; [...] Numa visão global, a administração é, pois todo o aparelhamento do Estado preordenando à realização de serviços, visando à satisfação das necessidades coletivas." ${ }^{\text {46 }}$

Nessa mesma linha, reforça a definição Sylvia Zanella Di Pietro

"Em sentido subjetivo, formal ou orgânico, ela designa os entes que exercem a atividade administrativa; compreende pessoas jurídicas, órgãos e agentes públicos incumbidos de exercer uma das funções em que se triparte a atividade estatal: a função administrativa;

Em sentido objetivo, material ou funcional, ela designa a natureza da atividade exercida pelos referidos entes; nesse sentido, a administração pública é a própria

\footnotetext{
${ }^{45}$ GASPARINI, Diógenes. Direito Administrativo. 10. ed. rev. e ampl. São Paulo: Saraiva, 2004. p. 102.

${ }^{46}$ MEIRELLES, Hely Lopes. Direito Administrativo Brasileiro, 28. ed. São Paulo, Malheiros, 2003. p. 63.
} 
função administrativa que incumbe, predominantemente, ao Poder Executivo." ${ }^{47}$

O conceito de Administração Pública para fins penais é mais extenso, conforme ensinam Antônio Pagliaro e Paulo José da Costa Junior:

"Por administração pública, portanto, o Código Penal não entende apenas a
atividade administrativa em sentido estrito, distinta da atividade legislativa ou
jurisdicional. Muito ao contrário, o Código Penal leva em consideração toda a
atividade estatal, nem sentido subjetivo e noutro objetivo. Sob a angulação
subjetiva, a administração pública é entendida como o conjunto de entes que
desempenham funções públicas. Sob o aspecto objetivo, considera-se como
administração pública toda e qualquer atividade desenvolvida para satisfação do
bem comum. Em outras palavras: em direito penal, administração pública equivale
a sujeito-administração e atividade administrativa" 4 . Na criação do Título XI - "Dos crimes Contra Administração Pública" do Código Penal, o legislador teve a intenção de tipificar condutas que agridam qualquer dos elementos que integrem o seu conceito, seja ele subjetivo ou objetivo, isto é, intentou perseguir ações que atrapalhem o desenvolvimento regular da atividade estatal e de seus entes, consoante Edgar Magalhães Noronha ${ }^{49}$. Além disso, o legislador optou por dividir o mencionado título em capítulos, sendo certo que um deles dispõe somente sobre aqueles cometidos por funcionário público, conhecidos como crimes funcionas: Capítulo I - Crimes Praticados por Funcionários Públicos Contra a Administração Pública em Geral. É neste capítulo que consta o crime de peculato (artigo 312, 313, 313-A e 313-B do Código Penal).

O Código Penal em seu artigo 327, traz norma penal interpretativa que dispõe sobre o conceito de servidor público ${ }^{50}$ : “considera-se funcionário público, para efeitos penais, quem, embora transitoriamente ou sem remuneração, exerce cargo, emprego ou função pública" ${ }^{" 51}$.

Portanto, ao definir o referido conceito no Código Penal, o legislador teve a intenção de ampliá-lo, para um alcance maior da norma penal, elevando tal categoria para até mesmo aqueles servidores que atuam

\footnotetext{
${ }^{47}$ DI PIETRO, Maria Sylvia Zanella. Direito Administrativo. São Paulo: Atlas, 2006. p. 68.

${ }^{48}$ PAGLIARO, Antônio; COSTA JUNIOR, Paulo José da. Dos crimes contra a administração pública. São Paulo: Malheiros Editores, 1997, p. 16.

${ }^{49}$ NORONHA, Edgard Magalhães. Direito penal. V. 4. 19. ed. São Paulo: Saraiva, 1988..p. 198.

${ }^{50} \mathrm{O}$ Código Penal usa o termo funcionário público por ser anterior a Constituição Federal que usa o termo "servidor público".

${ }^{51}$ BRASIL. Decreto-lei n 2.848, de 7 de dezembro de 1940. Código Penal
} 
gratuitamente no setor público. Assim, para efeitos penais funcionário público não tem o mesmo conceito empregado no âmbito do direito administrativo, abrange não somente os funcionários titulares de cargo, por meio de concurso público, mas sim todos os funcionários, inclusive os que exercem a função pública sem remuneração percebida.

Neste sentido, leciona Fernando Capez:

"No âmbito administrativo, é bastante restrito o conceito de funcionário público, consistindo em mera espécie de agente administrativo, o qual, por sua vez, também pertence a um gênero mais amplo, denominado agente público. Desse modo, o conceito mais amplo é o de agente público, entendendo-se como tal qualquer pessoa que exerça, a qualquer título, ainda que transitoriamente e sem remuneração, função pública[...]. Conforme se percebe, funcionário público é apenas umas das espécies de agente administrativo, inserida no amplo rol de servidores pertencentes ao gênero "agente público" 52 .

Isto posto, verifica-se que o delito de peculato, abrange tanto o funcionário público stricto sensu, como também aqueles entendidos de forma lato sensu. Portanto, partindo desse entendimento, aquele que atuar em alguma função pública, ainda que em caráter não remunerado, permanente ou interinamente, para fins penais será identificado como funcionário público.

No entanto, não se deve confundir função pública com "múnus público", entendido como encargo ou ônus conferido pela lei e imposto pelo Estado em determinadas situações, a exemplo do que ocorre com os tutores, curadores etc." 53

A Lei $n^{\circ} 9.983$ de 2000 alterou o $\$ 1^{\circ}$ do artigo $327^{54}$ do Código Penal e estendeu o que se considera por funcionário público equiparado, incluindo além daqueles que exercem cargo, emprego ou função pública em empresa paraestatal, aqueles que trabalham em empresa prestadora de serviço contratada ou conveniada para a execução de atividade típica da

\footnotetext{
${ }^{52}$ CAPEZ, Fernando. Curso de Direito Penal - Parte Geral, artigos $1^{\circ}$ a $120^{\circ}$. São Paulo: Saraiva, v. 01,19 e. 2015. p. 442-443.

${ }^{53}$ GRECO, Rogério. Código Penal Comentado. 11 a ed. Niterói: Impetus, 2017, p. 1674.

54 “\$ $1^{\circ}$ - Equipara-se a funcionário público quem exerce cargo, emprego ou função em entidade paraestatal, e quem trabalha para empresa prestadora de serviço contratada ou conveniada para a execução de atividade típica da Administração Pública."
} 
Administração Pública.

A título de exemplo, é possível observar o julgamento do AgRg no REsp $1168892^{55}$, no qual um jovem aprendiz contratado pelo CIEE para prestar serviço junto à Caixa Econômica Federal, prospectando tomadores de microcrédito, equiparava-se a funcionário público. Na situação, o sujeito, aproveitando-se de sua condição, subtraiu o dinheiro de um aposentado, conduta que se amolda ao crime de peculato (artigo $312, \S 1^{\circ}$, do Código Penal).

Vale ressaltar, neste ponto, que existem algumas controvérsias quanto ao tema e a aplicação da terminologia funcionário público equiparado. Não há um entendimento unânime acerca da possibilidade de um funcionário público equiparado figurar da mesma forma como sujeito passivo dos delitos contra Administração Pública. Assim, a doutrina divide-se entre os que defendem que o funcionário público equiparado, somente irá figurar como sujeito ativo da ação, e os que defendem a possibilidade deles poderem figurar também como sujeitos passivos.

O $\S 2^{\circ}$ do artigo 327 do Código Penal, traz, ainda, uma causa de aumento, assim disposta:

"Ocupantes de cargos em comissão ou de função de direção ou assessoramento de órgão da administração direta, sociedade de economia mista, empresa pública ou fundação instituída pelo poder público." 56

Sobre ela, divide-se a doutrina quanto ao seu teor, se restringe a equiparação e a majorante às pessoas expressamente mencionadas (teoria restritiva) ou se a restrição se dá apenas em face desta última (teoria extensiva). Neste último caso todos os funcionários das entidades mencionadas, ocupando ou não cargos em comissão ou em função de direção e assessoramento, equiparam-se a funcionários públicos para fins penais, mas somente diante dessa condição citada incidirá a causa de aumento, conforme

\footnotetext{
${ }^{55}$ STJ, AgRg no AREsp: 1168892 /SP 2017/0241544-6, Ministro Relator Joel Ilan Paciornik, Quinta Turma, Data de Julgamento: 05/02/2018.

${ }^{56}$ BRASIL. Decreto-lei no 2.848, de 7 de dezembro de 1940. Código Penal. Rio de Janeiro, RJ, Dez, 1940.
} 
ensina Cleber Masson. ${ }^{57}$

Pode-se concluir que o legislador, ao criar os tipos incriminadores contra a Administração Pública, tinha como objetivo dar um amparo maior aos bens públicos, assim como resguardar, a probidade, a fidelidade ao setor público e a moralidade administrativa, acerca deste último Helly Lopes Meireles ensina:

"[...] o certo é que a moralidade do ato administrativo juntamente a sua legalidade e finalidade. Além da sua adequação aos demais princípios constituem pressupostos de validade sem os quais toda a atividade pública será ilegítima e ainda conclui que no âmbito infraconstitucional, o Decreto 1.171 de 22 de junho de 1994, aprovando o Código de Ética Profissional do Servidor Público Federal, reafirmou o princípio da moralidade administrativa, dispondo textualmente que o servidor jamais poderá desprezar o elemento ético de sua conduta, devendo decidir não somente entre 'legal e o ilegal, o justo e o injusto, o conveniente do inconveniente, o oportuno do inoportuno, mas principalmente o honesto do desonesto', consoante as regras contidas no artigo 37, 'caput' e $\S 4^{\circ}$ da Constituição Federal; por fim a Lei $\mathrm{n}^{\circ}$ 9784/99, consagra o princípio da moralidade administrativa, dizendo que ele significa a atuação segundo padrões éticos de probidade, decoro e boa-fé"

\subsection{Crimes Funcionais}

Após delinear o conceito de servidor público para o Direito Penal, é possível entender o que se tratam os crimes funcionais, que são aqueles cometidos por agentes que encontram-se investidos da função pública. Tais crimes são divididos pela doutrina em duas espécies: próprios e impróprios.

Os crimes funcionais próprios são aqueles nos quais sem a figura do funcionário público não se materializa a tipicidade, ou seja, considera-se o fato atípico, não podendo ser classificado em outro tipo penal, a exemplo o crime de abandono de função (artigo 323 do Código Penal). Por sua vez, os crimes funcionais impróprios são aqueles nos quais quando o agente não ostenta essa condição, o fato será classificado em outro tipo penal que não o crime funcional.

Algumas modalidades do crime de peculato, como as previstas na

${ }^{57}$ MASSON, Cleber. Código Penal Comentado. $2^{\mathrm{a}}$ ed. São Paulo, 2014. p. 1173. 
primeira parte do Caput (peculato apropriação), e em seu $\S^{\circ}$ (peculato furto) do artigo 312, tratam-se de crimes funcionais impróprios, uma vez que quando não cometido por funcionário público passam a ser classificados como apropriação indébita ou furto (artigos 168 e 155 do Código Penal).

Importante pontuar que apesar da lei ser taxativa quanto à necessidade de se ter como sujeito ativo no delito de peculato um agente público, há a possibilidade de um particular vir a responder pelo crime funcional na hipótese em que o delito é cometido em concurso com funcionário público, já que esta condição é elementar desses tipos, e, portanto, se comunica, desde que a condição seja de conhecimento do particular, conforme artigo 30 do Código Penal.

\subsection{Breve Histórico do Crime de Peculato}

O crime de peculato tem suas origens no Direito Romano, e esta palavra deriva do latim: peculatus, de peculari, de pecus, que significa gado, o que representava a riqueza da época, já que não havia ainda a moeda, e eram destinados aos sacrifícios oferecidos aos Deuses, constituindo riqueza pública, uma vez que a res sacrae não se diferenciava da res publica. Logo, o peculato tratava não só do furto, como da apropriação indébita em relação às coisas pertencentes ou consagradas aos deuses, como ensina Nélson Hungria $^{58}$.

Diversamente da legislação atual, naquela época não se levava em consideração à condição do agente, podendo figurar como autor desse delito tanto funcionários públicos como particulares. O que importava para considerá-lo era o caráter público ou sacro da res.

Sobre o tema, Cezar Roberto Bitencourt:

"O crime de peculato tem suas raízes remotas no direito romano e caracterizava-se pela subtração de coisas pertencentes ao Estado. Essa infração penal recebia o

\footnotetext{
${ }^{58}$ HUNGRIA, Nelson. Comentários ao Código Penal. V. IX. Rio de Janeiro: Ed. Revista Forense,
} 1959. p. 330. 
nome de peculatos ou depeculatus, oriundo de período anterior à introdução da moeda, quando os animais (bois e carneiros) destinados ao sacrifício em homenagem às divindades consistiam na riqueza pública por excelência. Na verdade, o gado representava o patrimônio mais importante da sociedade da época, que o utilizava como moeda primitiva." ${ }^{59}$

No Brasil, entre 1603 e 1830, época em que se aplicavam as Ordenações Filipinas, já se previa o peculato. Em 1830, no Código Criminal do Império este delito se encontrava nos “Crimes Contra o Tesouro Público e Propriedade Pública". Ainda mais à frente, no Código Republicano de 1890, o mesmo foi classificado da seguinte maneira:

"Subtrair, consumir ou extraviar dinheiro, documentos, efeitos, gêneros ou quaisquer bens pertencentes à Fazenda Pública, confiados à sua guarda ou administração, ou à de outrem, sobre quem exerça fiscalização em razão do ofício; consentir, por qualquer modo, que outrem se aproprie indevidamente desses mesmos bens, os extravie ou consuma em uso próprio ou alheio." ${ }^{10}$

A Lei 2.110 de 1909, em seu artigo $2^{\circ}$, dispunha que o agente era isentado de pena privativa de liberdade, somente perdendo o cargo público e sendo impossibilitado de exercer a função pública por 5 (cinco) a 15 (quinze) anos, desde que restituísse ou ressarcisse integralmente o prejuízo. Posteriormente, a Consolidação das Leis Penais em 1932, conhecida como Código Piragibe, restringiu a isenção pelo ressarcimento ao peculato culposo.

Em 1940, o Código Penal tipificou o peculato em seu “Título XI-Dos Crimes Contra a Administração Pública”, especificamente em seu "Capítulo I-Dos Crimes Praticados por Funcionário Público Contra a Administração em Geral" artigos 312 e 313, os quais se encontra em vigor até a presente data, estando dispostos nos seguintes termos:

“Art. 312 - Apropriar-se o funcionário público de dinheiro, valor ou qualquer outro bem móvel, público ou particular, de que tem a posse em razão do cargo, ou desviálo, em proveito próprio ou alheio.

Pena - reclusão, de dois a doze anos, e multa.

$\S 1^{\circ}$ Aplica-se a mesma pena, se o funcionário público, embora não tendo a posse do dinheiro, valor ou bem, o subtrai, ou concorre para que seja subtraído, em proveito próprio ou alheio, valendo-se de facilidade que lhe proporciona a qualidade de funcionário.

\footnotetext{
${ }^{59}$ BITENCOURT, Cezar Roberto. Tratado de Direito Penal-Parte especial: dos Crimes Contra a Administração Pública e dos Crimes Praticados por Prefeitos. Ampliada e atualizada. São Paulo: Saraiva, v. 05,08 e. 2014.565 p. 38

${ }^{60}$ BRASIL. Decreto n ${ }^{\circ}$ 847, de11 de outubro de 1890. Código Penal dos Estados Unidos do Brazil.
} 
$\S 2^{\circ}$ Se o funcionário concorre culposamente para o crime de outrem:

Pena - detenção, de três meses a um ano.

$\S 3^{\circ}$ No caso do parágrafo anterior, a reparação do dano, se precede à sentença irrecorrível, extingue a punibilidade; se lhe é posterior, reduz de metade a pena imposta.

Art. 313. Apropriar-se de dinheiro ou qualquer utilidade que, no exercício do cargo, recebeu por erro de outrem:

Pena - reclusão, de um a quatro anos, e multa." ${ }^{\prime 61}$

A Lei $n^{\circ} 9.983$ de 2000 ainda inseriu os tipos presentes nos artigos

313-A e 313-B, conhecidos como peculato eletrônico:

“Art. 313-A. Inserir ou facilitar, o funcionário autorizado, a inserção de dados falsos, alterar ou excluir indevidamente dados corretos nos sistemas informatizados ou bancos de dados da Administração Pública com o fim de obter vantagem indevida para si ou para outrem ou para causar dano:

Pena - reclusão, de 2 (dois) a 12 (doze) anos, e multa.

Art. 313-B. Modificar ou alterar, o funcionário, sistema de informações ou programa de informática sem autorização ou solicitação de autoridade competente:

Pena - detenção, de 3 (três) meses a 2 (dois) anos, e multa.

Parágrafo único. As penas são aumentadas de um terço até a metade se da modificação ou alteração resulta dano para a Administração Pública ou para o administrado." 62

Conclui-se que a previsão do delito de peculato tem como objetivo tutelar o bem jurídico Administração Pública, tanto em face da sua moralidade, quanto do seu caráter patrimonial. O seu objeto material dependerá de sua modalidade. Trata-se de crime próprio, que tem como sujeito ativo o funcionário público, podendo o particular vir a responder por este delito na hipótese do artigo 30 do Código Penal (com algumas exceções como no caso do peculato culposo). O sujeito passivo é o Estado e a pessoa física ou jurídica diretamente lesada pela conduta. Em regra, possui como elemento subjetivo o dolo, mas também sendo previsto na sua modalidade culposa. Todas as modalidades são passíveis de tentativa, excetuando-se a modalidade culposa. A ação penal em todos os tipos de peculato será pública incondicionada.

\footnotetext{
${ }^{61}$ BRASIL. Decreto-lei no 2.848 , de 7 de dezembro de 1940. Código Penal. Rio de Janeiro, RJ, Dez, 1940.

${ }^{62}$ BRASIL. Decreto-lei nº 2.848, de 7 de dezembro de 1940. Código Penal. Rio de Janeiro, RJ, Dez, 1940.
} 
No próximo subcapítulo far-se-á uma análise mais específica acerca de cada modalidade do delito de peculato.

\subsection{Modalidades de Peculato}

O crime de peculato possui sete modalidades, sendo elas: peculato apropriação, peculato desvio, peculato furto, peculato culposo, peculato uso, peculato mediante erro de outrem e peculato eletrônico.

A primeira hipótese, previsto na primeira parte do caput do artigo 312 do Código Penal, é o peculato apropriação que ocorre quando o agente público toma para si dinheiro, valor (tudo aquilo que pode ser convertido em dinheiro) ou bem móvel (passível de remoção) público ou particular, sob qual tenha a posse em razão de sua função. Isto é, o agente inverte a posse da coisa, passando-se a se investir como se proprietário fosse assim dispondo do bem, alienando-o, consumindo o bem, etc. Logo, corresponde à apropriação indébita, porém praticada por funcionário público no exercício de sua função.

Nos ensinamentos de Rogério Greco:

"A conduta núcleo, portanto, constante da primeira parte do art. 312 do Código Penal é o verbo apropriar, que deve ser entendido no sentido de tomar como propriedade, tomar para si, apoderar-se indevidamente de dinheiro, valor ou qualquer outro bem móvel, público ou particular, de que tem a posse ou a detenção (embora o artigo só faça menção expressa àquela), em razão do cargo. Aqui, o agente inverte o título da posse, agindo como se fosse dono, vale dizer, com o chamado animus rem sibi habendi." ${ }^{63}$

A consumação do delito na hipótese citada se dará no instante em que o funcionário público começa a se investir como se dono fosse do bem público, não sendo necessário o prejuízo econômico efetivo para tal, uma vez que além do patrimônio do Estado, tutela-se a moralidade administrativa.

A segunda parte do caput do artigo 312 do Código Penal dispõe acerca do peculato desvio, também conhecido como peculato próprio. Neste caso o funcionário público no exercício de sua função desvia o dinheiro, valor ou

\footnotetext{
${ }^{63}$ GRECO, Rogério. Código Penal Comentado. 11ª ed. Niterói: Impetus, 2017, p. 1594.
} 
bem móvel, dando destinação diversa da que lhe era proposta, em benefício próprio ou alheio. O proveito a que a lei se refere, poderá ser tanto material quanto moral, podendo o agente usufruir de vantagens diversas não somente de cunho econômico. Portanto, podemos entender, que o funcionário público conscientemente age com o dolo de desviar a coisa de que detém posse em razão de sua função pública, privilegiando a si mesmo ou a terceira pessoa.

Sobre o tema, Cezar Roberto Bittencourt:

"O verbo núcleo desviar tem o significado, neste dispositivo legal, de alterar o destino natural do objeto material ou dar-lhe outro encaminhamento, ou, em outros termos, no peculato-desvio o funcionário público dá ao objeto material aplicação diversa da que lhe foi determinada, em benefício próprio ou de outrem." ${ }^{94}$

Faz-se mister destacar que o desvio precisa ser em benefício próprio ou alheio, uma vez que caso a beneficiária da conduta seja a própria Administração Pública, o crime será de emprego irregular de verbas ou rendas públicas, consoante artigo 315 do Código Penal ${ }^{65}$.

A consumação na hipótese de peculato desvio se dá no instante em que o funcionário público altera o destino da coisa pública, empregando fins diversos dos regulares ou próprios. Para consumação, não se faz necessário o alcance da finalidade visada pelo agente, bastando o mero desvio da coisa pública. O alcance do proveito próprio ou alheio não é exigido como obtenção da finalidade, nem tampouco é requisito para consumação do delito.

As duas modalidades de peculato presentes no caput do artigo 312 do Código Penal são conhecidas como peculato próprio, posto que o agente público está na posse lícita do bem móvel público ou particular sobre o qual recairá a ação deste delito. Pode-se afirmar que a tentativa, prevista no artigo 14, II do Código Penal, aplica-se a essas duas modalidades.

No $§ 1^{\circ}$ do artigo 312 do Código Penal encontra-se o peculato furto, também conhecido como peculato impróprio. Neste o funcionário público não tem a posse ou detenção do dinheiro, valor ou bem móvel, mas valendo-

\footnotetext{
${ }^{64}$ BITTENCOURT, Cezar Roberto. Tratado de direito penal. v. 5. Saraiva, São Paulo: 2013, $7^{\mathrm{a}}$ Ed. p. 47.

65 “Art. 315 - Dar às verbas ou rendas públicas aplicação diversa da estabelecida em lei”
} 
se da sua condição, pratica a subtração ou concorre para que terceiro a pratique.

Na primeira parte do parágrafo tem-se o núcleo "subtrair", sendo o próprio agente público que irá inverter o título da posse, e na segunda parte do parágrafo, há o núcleo “concorrer”, no qual a sua atuação se restringe à concorrência dolosa para a subtração efetuada por outrem, em ambos os casos valendo-se de sua condição funcional. Neste último caso faz-se necessário o concurso de agentes e o dolo por parte daquele que se encontra em exercício de função pública, já que em caso de culpa o agente público responderá por peculato culposo (artigo $312, \S 2^{\circ}$ do Código Penal) e o particular por furto (artigo 155 do Código Penal).

As duas formas de peculato furto se consumam com a posse tranquila sobre o dinheiro, valor ou bem móvel, ainda que por período curto, sendo admitida a tentativa nas duas situações.

Diversamente das demais modalidades já mencionadas, no peculato culposo, previsto no $\S 2^{\circ}$ do artigo 312 do Código Penal, a conduta do agente público não tem a finalidade dolosa de apropriar, desviar ou subtrair coisa pública. Neste caso, o agente, no dever funcional, age com negligência, imprudência ou imperícia, propiciando involuntariamente facilidades para que outrem se aproprie, desvie ou subtraia coisa pública ou em custódia da Administração Pública, podendo ser o agente alheio ao setor público ou funcionário público. Portanto, sempre que o funcionário público, no dever funcional permitir que outrem pratique o delito, em razão de sua inobservância ao dever objetivo de cuidado, este responderá pelo crime de Peculato culposo.

Nas palavras de Cleber Masson:

"O peculato culposo nada mais é do que o concurso não intencional pelo funcionário público, realizado por ação ou omissão - mediante imprudência, negligência ou desídia - para a apropriação, desvio ou subtração de dinheiro, valor ou qualquer outro bem móvel pertencente ao Estado ou sob sua guarda, por uma terceira pessoa, que pode ser funcionário público (intraneus) ou particular 
(extraneus). ${ }^{.66}$

Imprescindível que o terceiro aproveite-se dolosamente do descuido por parte do funcionário público, tratando-se de crime plurissubjetivo, além de ser necessário que não haja liame subjetivo entre o agente público e o sujeito ativo da pratica delituosa, hipótese em que aquele responderia pelo crime na modalidade dolosa. A título de exemplo, cita-se o funcionário público que se esquece de trancar a porta da repartição, a qual é furtada por terceiro que adentra pela janela, não havendo, portanto, nexo causal entre as condutas, logo, não há que se falar em peculato culposo.

A consumação do crime de peculato se dá no momento em que a conduta dolosa por parte de outrem se aperfeiçoa e não se admite tentativa. Caso o crime doloso por parte de terceiro não chegue a se consumar, configurando apenas uma tentativa, não haverá a consumação do peculato culposo.

O peculato culposo é infração de menor potencial ofensivo, tendo como juízo competente para processar e julgar a ação respectiva o Juizado Especial Criminal, sendo compatível com os benefícios instituídos pela Lei $\mathrm{n}^{\text {o }} 9099$ de 1995.

O $\S 3^{\circ}$ do artigo 312 do Código Penal contempla a hipótese de reparação do dano, que pode se dar com a devolução do objeto ou com o ressarcimento do prejuízo. Caso este anteceda a sentença criminal irrecorrível, haverá a extinção de punibilidade e caso seja posterior reduz-se à metade a pena imposta. Pontue-se que a reparação do dano ou a extinção de punibilidade não acarretarão impedimento para eventual sanção administrativa, ante o ilícito funcional.

O Peculato de uso, que consiste na conduta do funcionário público que faz uso momentâneo e sem animus domini de bens pertencentes à Administração Pública, sob sua posse em virtude do cargo que ocupa, não configura crime, desde que os bens tenham natureza de coisa infungível e,

\footnotetext{
${ }^{66}$ MASSON, Cleber. Código Penal Comentado. 2a ed. São Paulo, 2014. p. 1115.
} 
após sua utilização, sejam devolvidos em perfeito estado para a Administração Pública, assim como no furto de uso.

No caso em que o funcionário público se utiliza de serviço público em proveito próprio ou alheio, valendo-se de sua condição, tem-se entendido que devido ao fato do objeto material dos diversos tipos de peculato tratar somente de "bem, valor ou dinheiro", essa conduta seria atípica, observandose o princípio da taxatividade penal, conforme julgamento do AP $504{ }^{67}$ pelo Supremo Tribunal Federal.

Em que pese as condutas acima não configurarem crime, o agente poderá vir a responder por ato de improbidade administrativa, conforme inciso IV, do artigo $9^{\circ}$ da Lei 8.429 de $1992^{68}$.

Quanto ao uso do dinheiro, ainda que momentaneamente, tem-se afastado a possibilidade de classificá-lo como peculato de uso e, consequentemente, entendendo tratar-se de fato típico, devido ao seu caráter fungível. Nesse sentido decidiu o STF no julgamento do Inq $3108^{69}$ e STJ no julgamento do HC 238.12970. Nas palavras de Julio Fabbrini Mirabette:

"Não procede a alegação de atipicidade pelo mero uso do dinheiro, bem fungível. Dinheiro, como previsto no próprio tipo penal em comento, transcrito linhas supra, também é objeto material do crime de peculato, assim como valor (títulos da dívida pública, apólices, letras de câmbio etc.) ou qualquer bem móvel, sejam públicos ou particulares, que estejam em custódia, guarda ou vigilância do Estado"71

No caso em que o peculato de uso tiver como sujeito ativo da conduta um prefeito municipal, podendo o objeto material ser dinheiro, valor, bem público ou particular sob a tutela da Administração Pública e serviços públicos, este responderá criminalmente, nos termos do artigo $1^{\circ}$, II, do

\footnotetext{
${ }^{67}$ STF, AP 504 / DF, Ministra Relatora Cármen Lúcia, Segunda Turma, Data de Julgamento: 01/08/2017.

68 "Constitui ato de improbidade administrativa importando enriquecimento ilícito (...): IV - utilizar, em obra ou serviço particular, veículos, máquinas, equipamentos ou material de qualquer natureza, de propriedade ou à disposição de qualquer das entidades mencionadas no art. $1^{\circ}$ desta lei, bem como o trabalho de servidores públicos, empregados ou terceiros contratados por essas entidades;"

${ }^{69}$ STF Inq 3108/BA. Ministro Relator Dia Taffoli, Data de Julgamento: 15/12/2011.

${ }^{70}$ STJ HC 238129/TO 2012/0067620-2. Ministra Relatora Maria Thereza de Assis Moura. Data de Julgamento: 16/09/2014.

${ }^{71}$ MIRABETE. Julio Fabbrini. Código Penal interpretado. 5. ed. São Paulo: Atlas, 2005, p. 2313
} 
Decreto Lei 201 de $1967^{72}$.

O Peculato mediante erro de outrem, disposto no artigo 313 do Código Penal, também denominado como peculato estelionato, é considerado peculato impróprio, ou seja, como já visto, o agente público não tinha previamente a posse ou detenção, o que ocorre quando este aproveita-se da sua condição e do erro de outrem, que por um equívoco repassa um bem ou dinheiro passa para suas mãos e dele o mesmo se apropria.

Segundo Nelson Hungria, não importa a natureza desse erro, que pode versar sobre:

“a) sobre a competência do funcionário para receber; b) sobre a obrigação de entregar ou prestar; c) sobre o quantum da coisa a entregar (a entrega é excessiva, apropriando-se o agente do excesso). O tradens pode ser um extraneus ou mesmo outro funcionário (também no exercício de seu cargo). Pode acontecer que o funcionário accipiens venha a dar pelo erro do tradens só posteriormente ao recebimento, seguindo -se, só então, a indébita apropriação (dolus superveniens)",73

A doutrina divide-se quanto à necessidade do erro ser espontâneo. Para Nelson Hungria no caso em que o sujeito ativo provoque-o poderia estar-se diante de outra pratica delituosa, como por exemplo o estelionato. Já para Rogerio Greco não existe uma imposição da norma nesse sentido. Em suas palavras: "a lei penal não limita que o mencionado erro seja espontâneo, somente fazendo menção ao fato de que o agente tenha recebido o dinheiro ou qualquer utilidade mediante o erro de outrem." 74

Faz-se necessário que o funcionário público saiba que está se apropriando indevidamente do bem, sendo o dolo imprescindível. A consumação se dá no momento em que a referida apropriação ocorre, sendo admitida a tentativa.

O peculato mediante erro de outrem se trata de infração de médio potencial ofensivo, sendo compatível com a suspensão condicional do

\footnotetext{
72 "São crimes de responsabilidade dos Prefeitos Municipal, sujeitos ao julgamento do Poder Judiciário

$(\ldots)$ :

II - utilizar-se, indevidamente, em proveito próprio ou alheio, de bens, rendas ou serviços públicos."

${ }^{73}$ HUNGRIA, Nelson. Comentários ao Código Penal. v. IX. Rio de Janeiro: Ed. Revista Forense, 1959. p. 352.

${ }^{74}$ GRECO, Rogério. Código Penal Comentado. 11 a ed. Niterói: Impetus, 2017, p. 1606.
} 
processo, desde que cumpra os requisitos do artigo 89 da Lei 9.099 de 1995.

A Lei $\mathrm{n}^{\mathrm{o}} 9.983$ de 2000, introduziu os artigos 313-A e 313-B no Código Penal, sendo conhecidos como peculato eletrônico em razão do modo como os delitos são cometidos, ligados a sistemas eletrônicos, tendo como sujeito ativo o agente público.

O artigo 313- $\mathrm{A}^{75}$ do Código Penal trata de duas situações. Na primeira parte do caput faz menção à situação em que o funcionário público autorizado insere ou facilita a inserção de dados falsos nos sistemas informatizados ou bancos de dados da Administração Pública. Na segunda parte descreve a hipótese em que o agente altera ou exclui indevidamente dados corretos. Em ambos os casos, a finalidade de obter vantagem indevida para si ou para outrem ou para causar dano é exigida.

Ressalte-se que o termo "indevidamente", em relação aos núcleos "alterar" e "excluir", impõe a necessidade de que estes sejam praticados de forma contrária a lei ou ato normativo, já que na hipótese e serem praticados de forma devida e gerar prejuízo para Administração Pública não se vislumbra este crime.

Cumpre salientar que os "Dados, sejam eles falsos ou verdadeiros, são os elementos de informação ou representação de fatos ou de instruções, em forma apropriada para armazenamento, processamento ou transmissão por meios automáticos."76

Necessário se faz compreender os termos banco de dados e sistema informatizado, nas palavras de Guilherme de Souza Nucci:

"é o conjunto de elementos, materiais ou não, coordenados entre si, que funcionam
como uma estrutura organizada, tendo a finalidade de armazenar e transmitir dados,
através de computadores. Pode significar uma rede de computadores ligados entre
si, por exemplo, que transmitem informações uns aos outros, permitindo que o
funcionário de uma repartição tome conhecimento de um dado, levando-o a deferir

75 "Art. 313-A. Inserir ou facilitar, o funcionário autorizado, a inserção de dados falsos, alterar ou excluir indevidamente dados corretos nos sistemas informatizados ou bancos de dados da Administração Pública com o fim de obter vantagem indevida para si ou para outrem ou para causar dano"

${ }^{76}$ GRECO, Rogério. Código Penal Comentado. 11ª ed. Niterói: Impetus, 2017, p. 1606. p. 1609. (grifos originais) 
o pagamento de um benefício ou eliminar algum que esteja sendo pago. O sistema informatizado é peculiar de equipamentos de informática, podendo possuir um banco de dados de igual teor. Assim, a diferença existente entre o sistema informatizado e o banco de dados é que o primeiro sempre se relaciona aos computadores, enquanto o segundo pode ter, como base, arquivos, fichas e papéis não relacionados à informática" $"$.

Trata-se de crime instantâneo, não se prolongando no tempo, e crime formal, bastando a execução de um dos seus núcleos para que se consuma, ainda que o benefício visado não se concretize, sendo admitida a forma tentada.

Não se aplicam os benefícios previstos na Lei 9.099 de 1995, uma vez que se cuida de delito de elevado potencial ofensivo.

A hipótese que traz o artigo $313-\mathrm{B}^{78}$ do Código Penal é a que um funcionário público, sem a autorização ou solicitação da autoridade competente, modifica, ou seja, dá nova forma, ou altera sistema de informações ou programa de informática, hipótese em que faz mudanças ainda que sem desnaturar totalmente.

Diversamente do delito previsto no artigo 313-A do Código Penal, neste, o funcionário público não precisa ostentar qualidade específica, não sendo necessário fazer parte do quadro de pessoal autorizado, podendo ser sujeito ativo qualquer agente público.

Faz-se necessário delinear o conceito dos objetos materiais do crime a fim de se entender melhor a prática delituosa, sendo eles o sistema de informações e o programa de informática. O primeiro diz respeito "ao complexo de elementos físicos agrupados e estruturados destinados ao fornecimento de dados ou orientações sobre alguma pessoa ou coisa" 79 , enquanto que o segundo, conforme norma penal em branco homogênea, prevista no artigo $1^{\circ}$ da Lei $n^{\circ} 9.609$ de 1998 é:

“a expressão de um conjunto organizado de instruções em linguagem natural ou codificada, contida em suporte físico de qualquer natureza, de emprego necessário

\footnotetext{
${ }^{77}$ NUCCI, Guilherme de Souza. Código penal comentado. $6^{\text {a }}$ ed. São Paulo: RT, 2006, p.982.

78 "Art. 313-B. Modificar ou alterar, o funcionário, sistema de informações ou programa de informática sem autorização ou solicitação de autoridade competente"

${ }^{79}$ MASSON, Cleber. Código Penal Comentado. $2^{\mathrm{a}}$ ed. São Paulo, 2014. p. 1124.
} 
em máquinas automáticas de tratamento da informação, dispositivos, instrumentos ou equipamentos periféricos, baseados em técnica digital ou análoga, para fazê-los funcionar de modo e para fins determinados". ${ }^{80}$

O delito se consuma com a efetiva modificação ou alteração, não sendo necessário que da ação resulte algum prejuízo para a Administração Pública ou particular. Porém na hipótese em que isso ocorrer, o parágrafo único $^{81}$ do dispositivo em análise prevê a causa especial de aumento da pena privativa de liberdade e da sanção pecuniária.

Por fim, importante pontuar que esta última modalidade é compatível com os benefícios da Lei no 9.099 de 1995, por constituir infração penal de menor potencial ofensivo.

${ }^{80}$ BRASIL. Lei ${ }^{\circ} 9.609$, de 19 de fevereiro de 1898. A proteção da propriedade intelectual de programa de computador, sua comercialização no País, e dá outras providências. Brasília, DF, Fev., 1998.

81 "Parágrafo único. As penas são aumentadas de um terço até a metade se da modificação ou alteração resulta dano para a Administração Pública ou para o administrado" 


\section{CAPITULO 3 - APLICAÇÂO DO PRINCÍPIO DA INSIGNIFICÂNCIA AO CRIME DE PECULATO NA VISÃO DO STF E STJ}

Após a análise dos conceitos, origem histórica e demais fatores relevantes para a compreensão do princípio da insignificância e do crime de peculato isoladamente, neste capítulo propõe-se analisar como se dá a aplicação do referido princípio ao mencionado crime por parte do Supremo Tribunal Federal e do Superior Tribunal de Justiça.

O estudo do conjunto de decisões e interpretações das leis e princípios por parte dos tribunais superiores é de suma importância para a melhor compreensão e adaptação desses aos casos concretos. Isto porque, mesmo aquelas que não vinculam as decisões das instâncias inferiores, servem para estas como um norte, isto é, como verdadeiras fontes de interpretação.

No que diz respeito ao tema estudado, considerando-se que o princípio da insignificância não possui previsão legal, a jurisprudência e súmula editada pelos tribunais superiores se mostram ainda mais relevantes como fontes mediatas do direito, pois buscam fixar critérios e requisitos para a sua aplicação ou afastamento.

A aplicabilidade do princípio da bagatela sob a óptica do STF e STJ já foi abordada de maneira geral no Capítulo 1 - Princípio da Insignificância, em seu subcapítulo 1.3 - O Princípio da Insignificância no Direito Penal. O que se pretende agora é fazer uma análise dos requisitos estabelecidos de forma mais profunda e restrita ao crime de peculato.

\subsection{Decisões Proferidas Pelo Supremo Tribunal Federal}

O Supremo Tribunal Federal ao longo dos anos já se posicionou ora a favor, ora contrário à aplicabilidade do princípio da insignificância aos 
crimes praticados contra a Administração Pública, dentre eles o crime de peculato. Portanto, mostra-se oportuno selecionar alguns julgados e analisar pormenorizadamente os fundamentos baseados para justificar ou afastar a aplicação e qual entendimento prevalece atualmente.

Questão pacífica entre as turmas do STF é que a aplicação do princípio da insignificância fica condicionada à concomitância dos quatro requisitos já estabelecidos pela Corte, quais sejam: a) a mínima ofensividade da conduta do agente; b) a ausência de periculosidade social da ação; c) o reduzido grau de reprovabilidade do comportamento; d) a inexpressividade da lesão jurídica causada. O que é motivo de divergência, e será objeto da análise, é quando esses requisitos encontram-se cumpridos.

A priori, far-se-á a exposição e análise dos julgados que negaram a aplicação do princípio da insignificância, e, a posteriori, dos julgados que concederam a aplicação do mesmo.

O primeiro caso a ser analisado é o HC $128109^{82}$. De acordo com os autos, uma empregada da Empresa Brasileira de Correios e Telégrafos, valendo-se de sua condição, ter-se-ia apropriado do valor total de $\mathrm{R} \$ 2462$, 65. A defesa afirmava tratar-se de valor ínfimo e pediu a aplicação do princípio da insignificância. $\mathrm{O}$ juízo de primeiro grau a condenou pela prática do crime de peculato por quarenta e uma vezes em continuidade delitiva (artigo 312 c/c artigo 71 do Código Penal), à pena de 2 (dois) anos e 8 (oito) meses de reclusão, em regime aberto. Inconformada, a defesa apelou para o Tribunal Regional da $1^{\mathrm{a}}$ Região que deu parcial provimento ao recurso para tão somente conceder a gratuidade de justiça. Não satisfeita, a defesa interpôs recurso especial, não admitido na origem, e agravo para o STJ, ocasião em que o Ministro Relator negou provimento ao recurso. Houve agravo regimental e foi improvido. Por fim, a defesa impetrou habeas corpus ao STF pleiteando a aplicação do princípio da insignificância. 82 STF HC 128109/MG. Ministro Relator Teori Zavascki, Segunda Turma, Data de
Julgamento:08/09/2015. 
O Ministro Relator Teori Zavascki pontuou em seu voto que o STF já decidiu tanto pela aplicabilidade do princípio da insignificância aos crimes contra Administração Pública quanto pela não aplicabilidade e, portanto, é possível realizar uma análise do caso para se aferir qual seria a melhor medida a ser tomada. No mencionado caso, entendeu que a soma da quantia que foi apropriada indevidamente não poderia ser considerada de valor ínfimo e citou julgados $^{83}$ do próprio STF que abordando valores que tornavam impossível a consideração da insignificância. Estes valores tinham como parâmetro, na maior parte das vezes, o salário mínimo vigente na época do fato:

“(...) II - Na hipótese dos autos, tem-se que o valor do bem subtraído representava quase $25 \%$ do salário mínimo vigente à época dos fatos, de modo que não se pode afirmar que seja irrelevante ou ínfimo o valor do bem subtraído, o que impede o atendimento de um dos requisitos exigidos por esta Corte para a aplicação do princípio da insignificância, qual seja, a inexpressividade da lesão jurídica" ${ }^{84}$

A Segunda Turma, por unanimidade dos votos, nos termos do voto do Ministro Relator Teori Zavascki, negou provimento ao habeas corpus, afastando o princípio da bagatela do caso concreto.

A partir da leitura desse primeiro julgado citado, é possível concluir que é imprescindível que o valor material da coisa seja considerado de valor ínfimo para a aplicabilidade do princípio da insignificância, bem como que apesar de não existir um critério fixo sobre este valor para o STF, o parâmetro utilizado é o salário mínimo vigente. Caso o valor patrimonial do bem não seja ínfimo, sequer é necessário passar para a análise dos demais critérios, uma vez que a lesão jurídica causada não poderá ser considerada inexpressiva. Na ocasião, o Ministro Teori Zavascki não adentrou no mérito da conduta ter sido praticada por funcionário público, afastando de imediato o princípio da insignificância por considerar o elevado valor do bem material.

O segundo julgado a ser analisado é o HC $104787^{85}$. Trata-se do caso

\footnotetext{
83 STF HC 98159/MG, Ministro Relator Ricardo Lewandowski, Primeira Turma, Data de Julgamento de 11/03/2009; STF HC 118264/MG, Ministro Relator Teori Zavascki, Segunda Turma, Data de Julgamento de 05/08/2014; STF HC 118320/ES. Ministra Relatora Cármen Lúcia, Segunda Turma, Data de Julgamento:06/11/2013.

84 STF HC 115891/MG. Ministro Relator Ricardo Lewandowski, Segunda Turma, Data de Julgamento: 21/05/2013.

85 STF HC 104787/RJ. Ministro Relator Ayres Britto, Segunda Turma, Data de Julgamento:
} 
em que militares, supostamente, teriam se aproveitaram de sua função para subtrair munições do Centro de Operações Especiais do Rio de Janeiro/RJ, que foram avaliadas em $\mathrm{R} \$ 286,00$. Os réus foram condenados pela prática do crime de peculato-furto, descrito no artigo 303, $\S 2^{\circ}$ do Código Penal Militar ${ }^{86}$. A pena aplicada foi de 04 (quatro) anos de reclusão, em regime aberto, e a pena acessória foi a exclusão de todos das forças armadas. Inconformada, a defesa apelou para o Superior Tribunal Militar que rechaçou a aplicação do princípio da insignificância. Insatisfeita, a defesa impetrou habeas corpus ao STF.

No Supremo, o princípio da insignificância foi afastado sob o fundamento de que a conduta recaia sobre bem jurídico que se encontra ligado estritamente à hierarquia e disciplina militar, além da segurança da coletividade. Portanto, não seria possível concluir pela sua mínima ofensividade, tampouco pela inexpressividade da lesão. O habeas corpus foi denegado, unanimemente, pela Segunda Turma, nos termos do voto do Ministro Relator Ayres Britto. Nas palavras deste:

"Quero dizer: ainda que o valor das munições seja de pequena monta, obsta a pretensão do impetrante o fato de que o crime de peculato não se constitui, apenas, em lesão de cunho patrimonial. É delito que também atenta contra a "Administração Militar" (Título VII, capítulo I, do Código Penal Militar), o que faz a conduta dos pacientes ultrapassar os domínios da singela patrimonialidade pública."

Vale citar um caso semelhante a este último, que apesar de mais recente não julgou o mérito da ação penal, mas se mostra relevante para o presente estudo.

Trata-se do HC 108.168 ${ }^{87}$. De acordo com os fatos narrados, um

\footnotetext{
26/10/2010.

86 “Art. 303. Apropriar-se de dinheiro, valor ou qualquer outro bem móvel, público ou particular, de que tem a posse ou detenção, em razão do cargo ou comissão, ou desviá-lo em proveito próprio ou alheio:

Pena - reclusão, de três a quinze anos.

(...)

$\S 2^{\circ}$ Aplica-se a mesma pena a quem, embora não tendo a posse ou detenção do dinheiro, valor ou bem, o subtrai, ou contribui para que seja subtraído, em proveito próprio ou alheio, valendo-se da facilidade que lhe proporciona a qualidade de militar ou de funcionário."

87 STF HC 108168/PE. Ministro Relator Luís Roberto Barroso, Primeira Turma, Data de Julgamento: 19/08/2014.
} 
agente público foi preso em flagrante na posse de munições de uso restrito ${ }^{88}$ e uniformes militares. A Juíza Auditora da $7^{\circ}$ Circunscrição Judiciária Militar, discordando da manifestação do Ministério Público Militar que requereu o arquivamento do inquérito, determinou o encaminhamento dos autos ao Procurador Geral da Justiça Militar. Novo Promotor de Justiça Militar foi designado para atuar no feito e foi deferida a perícia do material apreendido. A perícia conclui que "os cartuchos intactos periciados aparentemente se prestam para o fim a que são destinados. Porém, vale ressaltar que não se descarta a possibilidade de cartuchos 'pinados' terem condições de serem deflagrados". O Paciente foi denunciado pelo crime de peculato furto (artigo $303, \S 2^{\circ}$ do CPM), contudo a denúncia foi rejeitada, tendo em vista que seria mínima a potencialidade de dano. Por sua vez, o STM entendeu haver justa causa para ação penal e, afastando o princípio da insignificância, deu provimento ao recurso em sentido estrito do Parquet. Inconformada, a defesa impetrou habeas corpus ao STF, requerendo o trancamento da ação penal, alegando tratar-se de denúncia inepta, uma vez que não indicava o prejuízo causado pelo agente, e ainda, requerendo ainda a aplicação do princípio da insignificância, pois a conduta do agente seria minimamente lesiva.

O Ministro Relator originário Joaquim Barbosa rejeitou a liminar. Posteriormente, o habeas corpus foi indeferido, unanimemente, pela Primeira Turma, nos termos do voto do Ministro Relator Luís Roberto Barroso. O Ministro considerou que a denúncia descrevia os fatos de forma suficiente, além dos indícios de autorias estarem embasados em fatos concretos, possibilitando a ampla defesa. Finalizou afirmando não entender a conduta como penalmente irrelevante, nos mesmos moldes dos

\footnotetext{
88 “ 01 (um) revólver de plástico preto, 01 (um) cartucho de munição antiaérea, 01 (um) cartucho de morteiro, 01 (um) par de algemas, 17 (dezessete) munições de calibre 7,62 $\mathrm{mm}$ pinadas e 04 (quatro) deflagradas, 07 (sete) munições de calibre 7,62mm de festim intactas, 02 (duas) munições de calibre $38 \mathrm{~mm}$ deflagradas e 06 (seis) pinadas, 01 (uma) munição de calibre 22 intacta e duas deflagradas e 06

(seis) pinadas, 01 (uma) munição de calibre 22 intacta e duas deflagradas, 02 (duas) munições de calibre 9mm deflagradas, 01 (uma) munição calibre $28 \mathrm{~mm}$ pinada e 03 (três) deflagradas..."
} 
fundamentos apresentados no habeas corpus 104.787 (citado acima).

O que se extrai desses últimos dois julgados é a necessidade de se analisar nos crimes em que a tutela não se restringe ao patrimônio, como no peculato, se a conduta lesou além do caráter material do bem jurídico, seu caráter imaterial, neste caso a moralidade administrativa. Isto é, ultrapassado o primeiro passo que é vislumbrar se a conduta lesou significativamente o patrimônio do Estado, o próximo passo é analisar se a conduta lesou a Administração Pública em face de sua moralidade.

É possível observar na fundamentação de muitos julgados mais recentes $^{89}$ há reafirmação dessa necessidade de se olhar para o objeto de tutela do crime de peculato tanto em seu caráter patrimonial como moral. Porém, esse entendimento não é pacífico na Corte Suprema.

Passamos a análise do HC $122388^{90}$. Cuida-se de processo em que um carcereiro policial teria, supostamente, se apropriou de um farol de milha, avaliado em $\mathrm{R} \$ 13,00$, que guarnecia motocicleta apreendida. $\mathrm{O}$ agente público foi condenado pela prática do crime de peculato furto, descrito no artigo 312, §2 do Código Penal, à pena de 2 (dois) anos de reclusão, em regime aberto, com a substituição da reprimenda corporal por restritiva de direitos. A sentença condenatória decretou, ainda, a perda do cargo público. Houve recurso de apelação perante o Tribunal de Justiça de São Paulo, que manteve a sentença condenatória. Inconformada, a defesa manejou habeas corpus perante o STJ, que denegou a ordem. Por fim, insurgindo-se contra o acórdão da Corte Superior, impetrou habeas corpus perante o STF.

O impetrante sustentou a possibilidade de se aplicar o princípio da insignificância ao caso, como já havia sido feito em outras oportunidades pela próprio STF em hipóteses semelhantes.

\footnotetext{
${ }^{89}$ Julgados analisados: STF HC 145768/SC. Ministro Relator Dias Toffoli. Data de Julgamento: 01/08/2017; STF HC 104787/RJ. Ministro Relator Ayres Britto, Segunda Turma, Data de Julgamento: 26/10/2010; STF HC 85184/RS. Ministro Relator Marco Aurélio, Primeira Turma, Data de Julgamento: 15/03/2005; STF HC 131117/RS. Ministro Relator Marco Aurélio, Primeira Turma, Data de Julgamento: 15/03/2005.

90 STF HC 112388/SP. Ministro Relator Ricardo Lewandowski, Segunda Turma, Data de Julgamento: 21/08/2012.
} 
A Segunda Turma, por maioria, concedeu a ordem para absolver o Paciente, empregando o princípio da insignificância ao fato, vencido o Ministro Relator Ricardo Lewandowski.

Em seu voto, o Ministro Ricardo Lewandowski esclareceu que o tipo penal do peculato não tem como pressuposto a ocorrência de um prejuízo econômico quantificável, e asseverando que o principal bem jurídico tutelado seria a probidade administrativa. Em razão disso, a conduta do carcereiro policial não poderia ser considerada insignificante, uma vez que, apesar do prejuízo econômico ao erário público não ser grande, a integridade da Administração Pública em geral foi posta em risco, e não se poderia levar em conta apenas a expressão econômica da lesão. Elucidou que o princípio da insignificância cabe nas hipóteses em que o Direito Penal não se mostra necessário, não sendo este o caso, uma vez que o comportamento não apresenta reduzido grau de reprovabilidade. Por fim, afirmou acreditar que a aplicação do referido instituto em casos como aquele poderia significar um incentivo à pratica de pequenos delitos por funcionários públicos contra a Administração Pública.

Os Senhores Ministros Cesar Peluso e Gilmar Mendes, concederam a ordem. O primeiro, sem se estender, pontuou que o próprio Estado desconsidera prejuízos maiores a seu patrimônio, por exemplo, em relação a tributos, para descaracterizar, por tipicidade, certos crimes, tendo em vista a insignificância da ação. Observa-se que no voto do Ministro, houve a utilização da analogia ao delito de Descaminho, tipificado no artigo $334^{91}$ do Código Penal, para qual a própria legislação elencou objetivamente as quantias $^{92}$ a serem consideradas como divisa para o reconhecimento e aplicação da insignificância material do delito.

No mesmo sentido, o Ministro Gilmar Mendes reconheceu a

\footnotetext{
91 “Art. 334. Iludir, no todo ou em parte, o pagamento de direito ou imposto devido pela entrada, pela saída ou pelo consumo de mercadoria”

${ }^{92}$ As portaria 75/2012 e 130/2012 do Ministério da Fazenda estabeleceram preveem a não execução dos débitos com a Fazenda Nacional nos casos de valores iguais ou inferiores à R\$20.000,00.
} 
insignificância na lesão causada, e ressaltou que o valor é diminuto, e provavelmente, envolvia bens que já estavam em desuso.

Passados cinco anos do julgamento citado acima, em 2017, o Ministro Ricardo Lewandowski, em decisão monocrática, decidiu mudar de posicionamento. No julgamento do HC $137899^{93}$, que tratava da apropriação indevida de quatro vale-refeição, cada um no valor de $\mathrm{R} \$ 13,00$, por parte de um inspetor da guarda municipal, no exercício da função.

No caso, o Ministério Público ofereceu denúncia em face do inspetor, imputando-lhe a prática de peculato apropriação, previsto no artigo 312 do Código Penal. A defesa impetrou habeas corpus ao Tribunal de Justiça do Paraná, alegando que os argumentos expostos na resposta escrita não foram examinados, tendo sido denegada a ordem. Insatisfeita, a defesa manejou habeas corpus em face do STJ, que não conheceu do writ, sob pena de supressão de instância. Houve embargos de declaração em face desse acórdão e foram rejeitados. Por fim, impetrou habeas corpus ao STF.

O impetrante sustentou que o valor do prejuízo supostamente causado ao Estado era irrisório, tendo sido ressarcido pelo Paciente no mesmo dia do ocorrido, devendo aplicar-se ao caso o princípio da insignificância, e, portanto, trancar a ação penal.

O Ministério Público Federal, em parecer da Subprocuradora de Justiça, manifestou-se pelo não conhecimento do habeas corpus e pela concessão da ordem de ofício e sinalizou que a conduta "passa ao largo da necessária expressividade penal exigível para a deflagração da persecução penal" e que não havia relevância penal suficiente para movimentar a máquina repressora do Estado.

O Ministro Ricardo Lewandowski citou em seu voto o julgamento do habeas corpus 112388 (último caso analisado), afirmando tratar-se de situação muito semelhante, ocasião em que teve seu voto vencido, decidindo,

\footnotetext{
${ }^{93}$ STF HC 137899/PE. Ministro Relator Ricardo Lewandowski, Data de Julgamento: 28/06/2017.
} 
o colegiado, pela aplicação do princípio da insignificância.

O Ministro esclareceu que naquela circunstância, em que pese o tipo penal presente no artigo 312 do Código Penal não exigir como pressuposto a ocorrência de um prejuízo patrimonial, já que seu objetivo primordial é tutelar a probidade administrativa, e mesmo entendendo que a conduta do agente trouxe enormes consequências negativas para à moral administrativa, foi concedida a ordem para reconhecer a atipicidade da conduta.

Posto isso, considerando-se o que havia sido decidido pelo colegiado, bem como a similaridade dos fatos, deveria ser reconhecida a atipicidade da conduta, razão pela qual conheceu parcialmente o habeas corpus e concedeu a ordem de ofício, nos seguintes termos:

"Destarte, ao reconhecer que o presente caso guarda consonância com aquele analisado no HC 112.388/SP, entendo que, ante a ausência de prejuízo à administração pública (houve ressarcimento do erário no mesmo dia do fato) e a desproporcionalidade da aplicação da lei penal, deve ser reconhecida a atipicidade da conduta."

O Eminente Ministro ainda finalizou o seu voto destacando que o desfecho na esfera penal não impedia a possibilidade da abertura de eventual procedimento administrativo disciplinar.

Da leitura dos dois últimos julgados, pode-se concluir que não é sempre que os Ministros do STF abordam o duplo caráter que o bem jurídico tutelado pelo peculato possui. O posicionamento da Suprema Corte é formulado de acordo com o caso concreto e a principal análise que deve ser feita para muitos Ministros é a intensidade da lesão material sofrida pela Administração Pública. Não se nega que a moral administrativa tenha sofrido algum tipo de lesão, mas isso não impede de forma absoluta a aplicação do princípio da bagatela aos casos em que se acredita ter a conduta sido minimamente lesiva.

Ademais, como bem salientado pelo eminente ministro Ricardo Lewandowski, ainda que a moralidade e a fidelidade administrativa sofram algum dano, este pode ser devidamente punido em outra esfera jurídica, mantendo intacto o caráter fragmentário e subsidiário do direito penal. 
Finalmente, vale análise do HC $112308^{94}$. Segundo os fatos narrados, um estagiário bolsista da Biblioteca Central da Universidade Federal de Santa Catarina, valendo-se de sua condição, teria subtraído 6 (seis) livros que correspondiam à importância de $\mathrm{R} \$ 100,00$. O acusado foi condenado pela prática de peculato-furto (artigo $312, \S 1^{\circ}$ do Código Penal), à pena de 2 (dois) anos e 4 (quatro) meses de reclusão, em regime aberto, tendo sido a pena privativa de liberdade substituída por duas restritivas de direito. Em sede de apelação o Tribunal Regional Federal da $4^{\circ}$ Região decidiu pela aplicação do princípio da insignificância ao caso, absolvendo o Apelante. O Ministério Público ofereceu REsp ao STJ que cassou o acórdão recorrido e reestabeleceu a sentença do juízo monocrático. A defesa agravou da decisão monocrática, tendo o agravo regimental sido desprovido. Inconformada, a defesa impetrou habeas corpus ao STF.

A defesa sustentou a possibilidade de se aplicar o princípio da insignificância à conduta do estagiário. Por sua vez, o Ministério Público Federal em parecer da Subprocuradora-Geral da República opinou pela denegação da ordem.

O Ministro Relator Celso de Mello assinalou em seu voto que há diversos precedentes ${ }^{95}$, inclusive alguns em que figurou como Relator, no sentido de excluir ou afastar a tipicidade penal, observada sob a sua óptica material, junto aos princípios da fragmentariedade e da intervenção Mínima do Estado em matéria penal. O Ministro pontua que a privação da liberdade e a restrição de direitos do indivíduo só se justificam em situações realmente necessárias à proteção das pessoas, sociedade e bens jurídicos essenciais, e tão somente em situações em que há dano efetivo ou potencial, causados por condutas impregnadas de lesividade. Concluiu afirmando que no caso em

\footnotetext{
${ }^{94}$ STF HC 112308/SC. Ministro Relator Celso de Mello. Data de Julgamento: 25/02/2014.

${ }^{95}$ Precedentes citados no voto do Ministro Celso de Mello: STF HC 92463/RS. Ministro Relator Celso de Mello. Data de Julgamento: 13/09/2007; STF HC 106510/MG. Ministro Relator Joaquim Barbosa. Segunda Turma. Data de Julgamento: 22/03/2011; STF HC 107264/DF. Ministro Relator Celso de Mello. Segunda Turma. Data de Julgamento: 19/04/2011; STF HC 87478/PA. Ministro Relator Eros Grau. Primeira Turma. Data de Julgamento: 29/08/2006; STF HC 88393/RJ. Ministro Relator Cezar Peluso. Segunda Turma. Data de Julgamento: 03/04/2007; STF HC 92463/RS. Ministro Relator Celso de Mello. Data de Julgamento: 13/09/2007;
} 
análise, considerando a lesão ínfima que o furto de seis livros causava ao patrimônio público, justificava-se a aplicabilidade do princípio da bagatela, e deferiu o pedido do habeas corpus em decisão monocrática.

Percebe-se que o Ministro Celso de Mello não deu tratamento diferenciado ao crime de peculato, tendo citado como exemplos de precedentes crimes de furto simples e lesão corporal leve decorrente de acidente de trânsito. Isto é, o julgador entendeu que o fato da conduta causar uma lesão a um bem que não possui unicamente caráter material, como é o caso da lesão corporal que agride a integridade física, desde que inexpressiva, não afastava necessariamente a aplicação do princípio da bagatela. Ademais, além de ter entendido que a lesão era inexpressiva, o Ministro entendeu também que a conduta era minimamente ofensiva, não trazendo periculosidade social e havendo reduzidíssimo grau de reprovabilidade.

O que se extrai do estudo da jurisprudência do Supremo Tribunal Federal é que não existe um entendimento sedimentado acerca da possibilidade em se aplicar o princípio da insignificância aos crimes de peculato. Há grande controvérsia entre os Ministros, e em dadas situações concede-se a ordem de ofício ainda que se entenda haver supressão de instância para afastar a tipicidade material do delito e absolver os acusados, reformando a sentença condenatória ou até mesmo determinando o trancamento da ação penal como foi o caso do HC 137899 (já citado) e em outros $\operatorname{casos}^{96}$ semelhantes entende-se não ser possível desconsiderar a supressão de instância ou admitir o habeas corpus em substituição de recurso próprio por não se tratar de hipótese de concessão da ordem de ofício.

Em algumas hipóteses a expressividade da lesão ao bem jurídico tutelado pelo peculato, qual seja a Administração Pública, será analisado pelos Ministros do Supremo com maior ênfase sob seu caráter patrimonial e em outras sob seu caráter moral. Ademais, os Ministros que se aprofundam

\footnotetext{
${ }^{96}$ STF HC 134090/SP. Ministro Relator Luiz Fux. Data de Julgamento: 04/05/2016; STF HC 132095/PB. Ministro Relator Edson Fashin, Data de Julgamento: 15/01/2016; STF HC 145768/SC. Ministro Relator Dias Toffoli, Data de Julgamento: 01/08/2017.
} 
na discussão sobre a lesão que a moralidade administrativa sofre neste tipo penal dividem-se entre os que entendem ser impossível mensurar o grau da lesão sofrida e os que admitem ser possível aferir os diversos graus de lesão, logo, para estes últimos, seria possível constatar uma lesão inexpressiva em relação à moralidade pública e não só ao seu caráter patrimonial.

Não há dúvidas que o Supremo Tribunal Federal, guardião da Constituição Federal, tendo como um dos seus principais papéis a uniformização do sistema jurídico e da interpretação legal, precisa sedimentar seu entendimento acerca da aplicabilidade do princípio da insignificância aos crimes de peculato, um dos mais recorrentes crimes contra a Administração Pública, a fim de evitar a temida insegurança jurídica.

\subsection{Decisões Proferidas Pelo STJ}

Há alguns anos a jurisprudência majoritária do Superior Tribunal de Justiça segue no sentido de entender ser inaplicável o princípio da insignificância aos crimes contra a Administração Pública, incluindo-se aqui o crime de peculato. Neste subcapítulo iremos abordar as razões que levam esta Corte Superior a decidir pela impossibilidade de se atribuir à conduta descrita pelo crime de peculato o caráter de bagatela ou de insignificância.

A Sexta Turma do Superior Tribunal de Justiça, em 2014, por maioria, deixou de conhecer do HC $246885^{97}$ e concedeu a ordem de ofício para afastar a tipicidade material de conduta descrita no tipo de peculato-furto (artigo 312, caput do Código Penal). O caso tratava da suposta apropriação indevida de vales-alimentação, por parte do responsável pelo Cartório da $375^{\mathrm{a}}$ Zona Eleitoral (São Mateus/SP), no valor de R \$15,00, que era destinado aos mesários nas Eleições Municipais de 2008. O agente público foi absolvido sumariamente em primeiro grau, tendo o Juízo da $7^{\text {a }}$ Vara Criminal

\footnotetext{
${ }^{97}$ STJ HC 246885/SP. Ministra Relatora Maria Thereza De Assis Moura. Sexta Turma. Data de Julgamento: 24/04/2014.
} 
de São Paulo/SP aplicado ao feito o princípio da insignificância. O Ministério Público manejou apelação ao Tribunal de origem que a proveu sob o fundamento de que seria inaplicável o princípio da insignificância aos crimes funcionais contra a Administração Pública. Inconformada, a defesa impetrou habeas corpus para o STJ.

A Ministra Relatora Maria Thereza de Assis Moura, que decidiu pela não concessão da ordem, em seu voto vencido pontuou que não verificava patente ilegalidade e fundamentou que a aplicação do princípio da insignificância estaria vinculada à concomitância dos requisitos objetivos estipulados pelo STF, cuja ocorrência não se verificava naquela caso. Ainda esclarece que:

"na espécie, não se trata apenas e tão-somente da questão patrimonial, mas do próprio bem jurídico tutelado, é dizer, a Administração Pública, vilipendiada com a conduta que é imputada ao paciente, em se apropriar, em razão do cargo, de valealimentação."

O Ministro Sebastião Reis Júnior relatou que em um primeiro momento manifestou concordância em relação à posição da Ministra Relatora, mas que ao realizar pesquisas na jurisprudência do STF, encontrou três precedentes, fazendo referência ao habeas corpus 112388 (citado no subcapítulo 3.1 - Decisões Proferidas Pelo STF), dentre outros. Portanto, no mesmo sentido daqueles julgados provenientes do STF, entendeu ser possível aplicar o princípio da insignificância mesmo se tratando de crime de peculato. Os Ministros Nefi Cordeiro e Rogerio Schietti Cruz acompanharam o voto do Ministro Sebastião Reis Júnior.

Apesar da concessão, percebe-se que essa decisão foi um caso isolado e não vingou no seio da Corte Superior. Ao fazer uma rápida busca em seu sítio é possível encontrar diversos julgamentos em que se decidiu-se não ser possível aplicar o princípio da insignificância aos crimes de peculato.

Exemplificando, no julgamento do AREsp $605810^{98}$, o Ministro Nefi Cordeiro negou provimento ao agravo e deixou de aplicar o princípio da

\footnotetext{
${ }^{98}$ STJ AREsp 605810/SP. Ministro Relator Nefi Cordeiro. Data de Julgamento: 04/08/2017.
} 
insignificância ao caso em que o auxiliar direto de um Comandante do bombeiro foi condenado pela prática de peculato-apropriação (artigo 312, caput do Código Penal), à pena de 2 (dois) anos e 11 (onze)meses de reclusão em regime aberto, e perda da função pública, tendo a pena privativa de liberdade sido convertida para uma restritiva de direito e uma pena pecuniária. Na ocasião, o agente público teria se apropriado indevidamente, em proveito da sua função, de equipamentos de informática (pen drive, dois hubs e um filtro de linha) pertencentes ao Corpo de Bombeiros de Tietê.

A defesa apelou ao Tribunal de Justiça de São Paulo que negou provimento ao recurso e entendeu não ser possível aplicar o princípio da insignificância ao caso concreto, uma vez que a conduta estava imbuída de perceptível gravidade, tornado a aplicação da Lei Penal indispensável. O TJSP negou seguimento ao recurso especial oferecido pela defesa, em razão das Súmulas $7^{99}$ do STJ e $284^{100}$ do STF. Por fim, a defesa agravou da decisão para o STJ.

Na Decisão Monocrática, o Ministro Nefi Cordeiro fundamentou que o acórdão recorrido encontrava-se em consonância com o entendimento firmado pelo STJ, qual seja o da impossibilidade de se aplicar o princípio da insignificância aos crimes contra a Administração Pública, e reitera que "a mens legis da norma visa resguardar não só o aspecto patrimonial, mas, notadamente, a moralidade administrativa, insuscetível de valoração econômica.". Ainda, afirmou que a perda da função pública deveria ser mantida, pois havia sido bem fundamentada pelo juízo monocrático que ressaltou haver completa incompatibilidade moral do réu com o exercício do cargo ou função pública.

Neste mesmo sentido decidiu o Ministro Joel Ilan Parcionik no julgamento do AREsp 957871. Segundo consta nos autos, um funcionário do pátio da Gerência e Fiscalização de Ceilândia, no exercício de sua função,

\footnotetext{
99 "A pretensão de simples reexame de prova não enseja recurso especial."

100 "É inadmissível o recurso extraordinário, quando a deficiência na sua fundamentação não permitir a exata compreensão da controvérsia."
} 
supostamente teria se apropriado de uma caixa de papelão que continha DVD's falsificados. O juízo monocrático condenou o acusado pela prática do crime de peculato-apropriação, descrita no artigo 312, caput do Código Penal, à pena de 02 (dois) anos de reclusão, em regime aberto, tendo sido substituída a pena privativa de liberdade por duas restritivas de direito. A defesa apelou dessa decisão, alegando não ter sido causado nenhum prejuízo à sociedade, tratando-se de crime de bagatela. O TJDFT negou provimento à apelação, assim como negou seguimento ao recurso especial oferecido pela defesa, que agravou para o STJ.

Na decisão monocrática, o eminente Ministro afastou a possibilidade de reconhecer a insignificância no caso, limitando-se em citar um trecho de um acordão que negava a aplicação do princípio da insignificância aos crimes contra a Administração Pública, nos seguintes termos:

"incabível a aplicação do princípio da insignificância aos delitos cometidos contra a Administração Pública, uma vez que a norma visa a resguardar não apenas a dimensão material, mas, principalmente, a moral administrativa, insuscetível de valoração econômica"101

No julgamento do AgRg em AREsp 10758 ${ }^{102}$, a Quinta Turma, unanimemente, negou provimento ao agravo nos termos do voto do Ministro Relator Felix Fischer que já havia decidido monocraticamente pela impossibilidade de se aplicar o princípio da insignificância ao caso concreto.

A conduta narrada nos autos foi a suposta apropriação indevida de uma jaqueta da Adidas, fruto de uma apreensão, por parte de um policial no exercício de sua função. O Juízo de primeiro grau condenou o acusado pela prática do crime de peculato-apropriação (artigo 312, caput do Código Penal), fixando a pena de 02 (dois) anos e 02 (dois) meses de reclusão, em regime aberto. O TJSC deu parcial provimento à apelação da defesa tão somente para rever a dosimetria da pena ${ }^{103}$ e afastou a aplicação do princípio

\footnotetext{
101 STJ AgRg no AREsp 572572/PR. Ministro Relator Jorge Mussi. Quinta Turma. Data de Julgamento: 08/03/2016.

${ }_{102}$ STJ AgRg no AREsp 1075872/SC. Ministro Relator Felix Fischer. Quinta Turma. Data de Julgamento: 15/03/2018.

${ }^{103} \mathrm{O}$ TJSC fixou a pena privativa de liberdade em 01 (um) ano e 04 (quatro meses) de reclusão, substituída por duas restritivas de direito.
} 
da insignificância. O tribunal de origem negou seguimento ao recurso especial oferecido pela defesa que agravou da decisão. O agravo foi desprovido pelo Ministro Relator Felix Fischer, ocasião em que a defesa opôs agravo regimental, o qual foi igualmente desprovido.

O pleito da defesa pela a aplicação do princípio da bagatela fundamentava-se no valor ínfimo do bem apropriado e na restituição do mesmo à vítima.

O Eminente Ministro Relator Felix Fischer, tanto do AgRg em AREsp, quanto do AREsp, citou os fundamentos do egrégio Tribunal de origem que ressaltou o quanto a conduta do agente feria diretamente princípios constitucionais primordiais para o bom funcionamento da administração pública, como legalidade, impessoalidade, moralidade e eficiência. Ainda afirmou que a punição do funcionário busca atender a própria sociedade que confiou ao agente seus interesses e este os obstruiu com sua conduta ilícita. Portanto, o bem jurídico tutelado sofre lesão independentemente do valor material da coisa apropriada, sendo a conduta altamente reprovável. Por fim, o Eminente Ministro corroborou os argumentos citando acórdãos ${ }^{104}$ do próprio STJ.

Outrossim, é possível listar inúmeros julgados ${ }^{105}$ em que o Superior Tribunal de Justiça, perfilhando do mesmo entendimento dos que foram citados neste trabalho, afastaram a aplicação do princípio da insignificância

\footnotetext{
104 STJ AgRg no AREsp 1382289/PR. Ministro Relator Jorge Mussi. Quinta Turma. Data de Julgamento: 05/06/2014; STJ RHC 59801/SP. Ministro Relator Nefi Cordeiro. Quinta Turma. Data de Julgamento: 28/06/2016.

${ }^{105}$ STJ HC 350661/MG. Ministro Relator Felix Fischer. Quinta Turma. Data de Julgamento: 21/02/2017; STJ HC 310458/SP. Ministro Relator Ribeiro Dantas. Quinta Turma. Data de Julgamento: 06/10/2016; STJ AgRg no AREsp 572572/PR. Ministro Relator Jorge Mussi. Quinta Turma. Data de Julgamento: 16/03/2016; STJ AgRg no AREsp 648194/SP. Ministro Relator Sebastião Reis Júnior. Sexta Turma. Data de Julgamento: 03/03/2016; STJ AgRg no AREsp 188151/SP. Ministro Relator Sebastião Reis Júnior. Sexta Turma. Data de Julgamento: 23/02/2016; STJ AgRg no AREsp 614524/MG. Ministro Relator Sebastião Reis Júnior. Sexta Turma. Data de Julgamento: 14/04/2015; STJ AgRg no AREsp 1382289/PR. Ministro Relator Jorge Mussi. Quinta Turma. Data de Julgamento: 05/06/2014; STJ RHC 59801/SP. Ministro Relator Nefi Cordeiro. Quinta Turma. Data de Julgamento: 28/06/2016. Neste mesmo sentido, após a publicação da Súmula 599 do STJ: STJ AgRg no AREsp 107872/SC. Ministro Relator Felix Fischer. Quinta Turma. Data de Julgamento: 15/03/2018. STJ AREsp 765216/RS. Ministro Relator Joel Ilan Paciornik. Data de Julgamento: 02/04/2018. STJ AgRg no AREsp 765216/RS. Ministro Relator Ilan Paciornik. Quinta Turma. Data de Julgamento: 24/04/2018.
} 
ao crime de peculato e à outros crimes contra a Administração Pública. O fundamento utilizado sempre recai sobre o fato de que os tipos penais dessa natureza possuem como bem jurídico tutelado a Administração Pública em seu caráter moral e não somente patrimonial, como já foi visto exaustivamente. Posto isso, para a Corte Superior, não seria possível atribuir as condutas desses tipos incriminadores a nenhum dos requisito objetivos fixados pelo STF.

\subsubsection{A Súmula 599 do STJ}

O Superior Tribunal de Justiça diante da sua jurisprudência sedimentada acerca da aplicabilidade do princípio da insignificância aos crimes contra a Administração Pública, bem como diante dos diversos julgamentos de casos análogos, e buscando orientar os Tribunais a quo, em 20 de novembro de 2017, através da sua Corte Especial, aprovou a Súmula 599 que dispõe: “O princípio da insignificância é inaplicável aos crimes contra a Administração Pública.”.

As Súmulas nada mais são do que o resumo do entendimento de um Tribunal a respeito de uma determinada matéria, decorrente de diversos julgamentos. O Código de Processo Civil de 2015 ao prever as regras de aplicação dos precedentes redimensionou a importância da jurisprudência, e, consequentemente das Súmulas. Vale a análise do artigo $489 \S 1^{\circ}$, VI e do artigo 927, inciso IV, ambos do referido Código de Processo ${ }^{106}$ :

“Art. 927. Os juízes e os tribunais observarão: (...) IV - os enunciados das súmulas do Supremo Tribunal Federal em matéria constitucional e do Superior Tribunal de Justiça em matéria infraconstitucional;"

“Art. 489. São elementos essenciais da sentença: (...) $\S 1^{\circ}$ Não se considera fundamentada qualquer decisão judicial, seja ela interlocutória, sentença ou acórdão, que: VI - deixar de seguir enunciado de súmula, jurisprudência ou precedente invocado pela parte, sem demonstrar a existência de distinção no caso em julgamento ou a superação do entendimento."

Segundo o entendimento majoritário, os precedentes judiciais e as

${ }^{106}$ BRASIL. Lei no 1.001 , de 21 de outubro de 1869. Código Penal Militar. Brasília, DF, Out., 1970. 
Súmulas dos tribunais superiores, a partir do CPC de 2015, passam a ser de observância obrigatória. O objetivo do legislador foi trazer instrumentos para buscar amenizar a morosidade processual e a insegurança jurídica. Isto é, a nova lei processual não retirou a liberdade do juiz, mas buscou resguardar o próprio sistema jurídico de opiniões individuais e isoladas, que só tendem a trazer insegurança, já que muitas vezes casos extremamente semelhantes chegavam a resultados diversos apenas por serem julgados por juízos diversos.

Sobre o tema, mostra-se importante ressaltar que a I Jornada de Direito Processual Civil estabeleceu em seu enunciado $n^{\circ} 3$ que "As disposições do CPC aplicam-se supletiva e subsidiariamente ao Código de Processo Penal, no que não forem incompatíveis com esta Lei"107. Da mesma forma estabelece o próprio Código de Processo Penal, que em diversas passagens atribui ao CPC caráter subsidiário, como em seu artigo $3^{\text {o108 }}$ que traz a possibilidade de se fazer uma interpretação extensiva e aplicação analógica. Logo, essa nova conjuntura aplica-se ao direito processual penal.

No que concerne à análise específica sobre o teor da Súmula 599 do STJ, o fato do seu enunciado prescrever a inaplicabilidade do princípio da insignificância em relação aos crimes contra a Administração Pública em geral, o que parece, inclusive considerando os precedentes que ensejaram a criação da referida Súmula, é que tal restrição se refere apenas aos crimes funcionais, uma vez que é em função desses que a moralidade administrativa é mais atingida, como ensina o professor Rogério Sanches Cunha ${ }^{109}$.

Ressalta-se que a Súmula 599 do STJ não se aplica ao crime de Descaminho descrito no artigo $334^{110}$ do Código Penal, em seu Título XI -

\footnotetext{
${ }^{107}$ BRASIL. Conselho da Justiça Federal. I Jornada de Direito Processual Civil. Brasília, DF, 24 e 25 de agosto de 2017.

108 “Art. 3 A lei processual penal admitirá interpretação extensiva e aplicação analógica, bem como o suplemento dos princípios gerais de direito."

${ }^{109}$ CUNHA, Rogério Sanches. Súmula 599 do STJ: Não se aplica o princípio da insignificância nos crimes contra a Administração Pública. Disponível em: < http://meusitejuridico.com.br/2017/11/20/sumula-599-stj-nao-se-aplica-o-principio-dainsignificancia-nos-crimes-contra-administracao-publica/>. Acesso em: 20 Mai 2018.

110 “Art. 334. Iludir, no todo ou em parte, o pagamento de direito ou imposto devido pela entrada,
} 
Dos Crimes Contra a Administração Pública, Capitulo II - Dos Crimes Praticados por Particular Contra a Administração em Geral. Isto é, os tribunais superiores aplicam o princípio da bagatela ao crime de descaminho quando as mercadorias possuem valores ínfimos ${ }^{111}$, sob o argumento de que a execução fiscal desses valores não compensa para o Fisco. Nos termos do STJ: "a insignificância nos crimes de descaminho tem colorido próprio, diante das disposições trazidas na Lei n. 10.522/2002"112.

A título de exemplo, no julgamento do REsp $1688878^{113}$, a Terceira Seção do STJ manteve o acórdão do TRF da $3^{\circ}$ Região que aplicou o princípio da insignificância ao caso em que a acusada encontrava-se na posse de mercadorias estrangeiras sem nota fiscal, o valor estimado dos tributos iludidos era de $\mathrm{R} \$ 16.054,59$ (dezesseis mil, cinquenta e quatro reais e cinquenta e nove centavos).

Assim, observa-se que diversamente do que ocorre no Supremo Tribunal Federal, onde há bastante divergência sobre a aplicação do princípio da insignificância ao crime de peculato, não podendo se afirmar com precisão sobre uma posição majoritária, no Superior Tribunal de Justiça há entendimento quase pacífico sobre a sua não incidência, em razão de ser considerado que o bem jurídico protegido não é meramente o patrimônio da Administração Pública, mas também seus princípios, dentre os quais especialmente a moralidade, atacada significativamente pela conduta classificada como crime de peculato.

\footnotetext{
pela saída ou pelo consumo de mercadoria"

${ }_{111}$ As portaria 75/2012 e 130/2012 do Ministério da Fazenda estabeleceram preveem a não execução dos débitos com a Fazenda Nacional nos casos de valores iguais ou inferiores à R $\$ 20.000,00$.

112 STJ REsp 1346879/SC. Ministro Relator Marco Aurélio Bellizze. Segunda Seção. Data de Julgamento: 26/11/2013.

113 STJ REsp 1688878/SP. Ministro Relator Sebastião Reis Júnior. Terceira Seção. Data de Julgamento: $04 / 04 / 2018$.
} 


\section{CONCLUSÃO}

O presente trabalho dignou-se a apresentar como tem se dado na prática, sob a óptica do STF e STJ, a aplicação do princípio da insignificância, relevante instrumento de limitação do jus puniendi do Estado, ao crime de peculato, que por sua vez se trata de um importante tipo incriminador que busca resguardar a Administração Pública tanto em relação a seu caráter material, como em relação a seu caráter moral.

A doutrina e a jurisprudência, sem grandes controvérsias, admitem ser possível utilizar o princípio da insignificância como balizador do Direito Penal. A principal controvérsia surge quando se busca delimitar os tipos de condutas que poderiam ser consideradas minimamente ofensivas, e sob que tipo de bens jurídicos poder-se-ia se admitir que uma lesão ou ameaça de lesão possuiria inexpressividade do ponto de vista penal. A grande questão que se levanta é se algum bem jurídico teria tamanha importância que qualquer conduta atentatória sobre ele já mereceria a proteção do Direito Penal, sob pena de, se não rechaçada, colocar em risco a integridade do ordenamento jurídico e seu objetivo maior, que é tornar possível a convivência social.

Nota-se que há uma corrente jurisprudencial muito forte, sobretudo no STJ, perfilhando o entendimento de que nos crimes de peculato, ainda que a conduta do agente recaia sobre bem de valor ínfimo, não seria possível atribuir-lhe caráter insignificante, tendo em vista que no momento em que deixou de se observar os preceitos do Direito, da ética e do interesse coletivo, a moralidade administrativa já teria sido lesionada significativamente. Ademais, devido ao fato da moralidade administrativa não ser quantificável, não seria possível associar o valor ínfimo a este bem jurídico.

$\mathrm{Na}$ análise dos julgados em que o princípio da insignificância foi aplicado ao crime de peculato, o que se pôde perceber foi uma supervalorização do caráter patrimonial do bem jurídico tutelado, além da 
ausência de enfrentamento em relação à questão da conduta ter causado danos à moralidade administrativa.

O legislador, ao criar o crime de peculato, tinha como objetivo resguardar a moralidade administrativa e o patrimônio público e particular sob a custódia do Estado. Caso não fosse assim, não haveria a necessidade de se criar um novo tipo incriminador com objetivo de tutelar o patrimônio, uma vez que já há outros tipos que se encarregam de fazer isso, como é o caso da apropriação indébita (artigo 168 do Código Penal) e do furto (artigo 155 do Código Penal). Ainda que o objetivo do legislador seja de punir mais severamente aqueles que atentem especificamente contra o patrimônio do Estado, continua sendo inegável que o seu principal objetivo é resguardar a moralidade pública, caso contrário não teria limitado esse tipo aos seus agentes públicos.

Neste diapasão, não se nega o quão importante é resguardar a moralidade administrativa, nem tampouco que as condutas nos crimes de peculato causam algum tipo de lesão a esta, mesmo quando o valor do dano patrimonial é irrisório. O que se pretende é detectar se a lesão em face dessa moralidade é de fato expressiva e se realmente não poderia ser resolvida em outra esfera do direito, como na própria esfera administrativa, que a depender do caso poderia aplicar as devidas sanções, como inclusive a perda do cargo, após apuração por meio de procedimento administrativo.

Em que pese a moralidade administrativa ser um bem jurídico extremamente relevante para o ordenamento e para a sociedade, não se pode concluir que toda e qualquer conduta que venha a trazer lesão ou ameaça de lesão para a mesma seja entendida como expressiva penalmente de forma absoluta, sob pena de igualar o tratamento dado aos que atentam contra este bem jurídico de forma significativa e aos que comentem ações que sequer possuem capacidade de abalar a referida moralidade. Não se pode admitir que condutas com potencialidade de dano em patamares tão diferentes sejam tratadas como se iguais fossem. 
A título de exemplo, não seria justo afirmar que o funcionário que se apropria indevidamente de uma resma de papel de uma repartição pública traz a mesma ofensa à moralidade administrativa que um policial que subtrai um bem pessoal, ainda que de valor ínfimo, em diligência policial na casa de um investigado. No primeiro caso, o funcionário não observou os ditames éticos e morais que se exige de um agente público e poderá responder administrativamente por isso. Porém, usar o Direito Penal, o último remédio do ordenamento jurídico, como a única forma de correção possível desse comportamento, é ferir a sua função social. No segundo caso foi confiada ao policial a tarefa de entrar na casa de um cidadão, restringindo o seu direito à inviolabilidade do asilo, resguardado pela Constituição Federal em seu artigo $5^{\circ}$, inciso $\mathrm{XI}^{114}$, em prol da aplicação do ordenamento e do interesse coletivo de reprimir supostas práticas delituosas, e o agente público se aproveita da confiança que lhe foi conferida pelo Estado e toma para si pertence pessoal daquele que se pretende investigar ou de sua família. Definitivamente, não parece razoável equiparar as condutas exemplificadas.

É inegável que a tarefa de avaliar o grau de dano sofrido por um bem que não se pode quantificar em valores precisos é extremamente difícil, mas é também por esta razão que não se pode determinar previamente que toda e qualquer ação fere de forma expressiva esse bem, sendo necessário avaliar caso a caso, como tem sido feito pelo Supremo Tribunal Federal. Trate-se de uma questão de justiça analisar cada caso concreto, aferindo se é razoável e proporcional a aplicação de uma sanção penal ou se a sanção administrativa ou civil bastaria. Assim, entende-se que desde que a decisão seja bem fundamentada e observe os princípios e normas do direito não há impedimento absoluto para que se aplique o princípio da insignificância aos crimes de peculato.

\footnotetext{
114 “Art. $5^{\circ}$ Todos são iguais perante a lei, sem distinção de qualquer natureza, garantindo-se aos brasileiros e aos estrangeiros residentes no País a inviolabilidade do direito à vida, à liberdade, à igualdade, à segurança e à propriedade, nos termos seguintes: XI - a casa é asilo inviolável do indivíduo, ninguém nela podendo penetrar sem consentimento do morador, salvo em caso de flagrante delito ou desastre, ou para prestar socorro, ou, durante o dia, por determinação judicial;",
} 
Em uma época em que se vive uma hipertrofia penal, o que se propõe não é o uso indiscriminado do princípio da insignificância como mecanismo descriminalizador, nem que se desconsidere a importância que o bem jurídico tutelado pelo peculato possui, tanto material quanto moral. Ao revés, propõese que se evitem soluções preestabelecidas engessando o ordenamento jurídico e vindo a causar possíveis injustiças, como no caso em que se nega indiscriminadamente a aplicação do princípio da insignificância a qualquer crime cometido contra a Administração Pública, presumindo que toda e qualquer ofensa a este bem jurídico seja relevante penalmente. Certo é que pior do que a insegurança jurídica é a certeza da injustiça. 


\section{BIBLIOGRAFIA}

ALEXY, Robert. Teoria dos Direitos Fundamentais. Tradução de Virgílio Afonso da Silva. 2. ed. São Paulo: Malheiros, 2011.

BECCARIA, Cesar. Dos Delitos e Das Penas. Prefácio: René Ariel Dotti. Tradução e Notas: Alexis Augusto Couto de Brito. São Paulo: Quartier Latin, 2005

BITTENCOURT, Cezar Roberto. Tratado de direito penal. v. 5. $7^{\mathrm{a}} \mathrm{Ed}$. Saraiva, São Paulo: 2013.

BITENCOURT, Cezar Roberto. Tratado de Direito Penal - Parte especial: dos Crimes Contra a Administração Pública e dos Crimes Praticados por Prefeitos. Ampliada e atualizada. v. 05. 08 Ed. São Paulo: Saraiva, 2014. BONAVIDES, Paulo. Curso de Direito Constitucional. $7^{\mathrm{a}}$ ed. São Paulo: Malheiros. 1997.

BRASIL. Constituição da República Federativa do Brasil: promulgada em 5 de outubro de 1988.

BRASIL. Decreto $\mathrm{n}^{\circ}$ 847, de 11 de outubro de 1890. Código Penal dos Estados Unidos do Brazil.

BRASIL. Lei $\mathrm{n}^{\circ}$ 1.001, de 21 de outubro de 1869. Código Penal Militar. Brasília, DF, Out., 1970.

BRASIL. Lei no 3.689, de 03 de outubro de 1941. Código Processo Penal. Rio de Janeiro, RJ, Out., 1941.

BRASIL. Decreto-lei no 2.848, de 7 de dezembro de 1940. Código Penal. Rio de Janeiro, RJ, Dez, 1940.

BRASIL. Lei $\mathrm{n}^{\mathrm{o}}$ 12.403, de 04 de maio de 2011. Alteração ao Código de Processo Penal.

BRASIL. Lei no 13.105, de 16 de março de 2015. Código Processo Civil. Brasília, DF, Mar., 2015. 
BRASIL. Lei n ${ }^{\circ} 9.609$, de 19 de fevereiro de 1898. A proteção da propriedade intelectual de programa de computador, sua comercialização no País, e dá outras providências. Brasília, DF, Fev., 1998.

BRASIL. Ministério da Fazenda. Portaria n 130. a inscrição de débitos na Dívida Ativa da União e o ajuizamento de execuções fiscais pela Procuradoria-Geral da Fazenda Nacional. 19. Abr. 2012.

BRASIL. Ministério da Fazenda. Portaria $n^{\circ} 75$. a inscrição de débitos na Dívida Ativa da União e o ajuizamento de execuções fiscais pela Procuradoria-Geral da Fazenda Nacional. 22. Març. 2012.

BRASIL. Conselho da Justiça Federal. I Jornada de Direito Processual Civil. Brasília, DF, 24 e 25 de agosto de 2017.

CAPEZ, Fernando. Curso de Direito Penal - Parte Geral: artigos $1^{\circ}$ a $120^{\circ}$. v. 01. 19 ed. São Paulo: Saraiva, 2015.

CUNHA, Rogério Sanches. Súmula 599 do STJ: Não se aplica o princípio da insignificância nos crimes contra a Administração Pública. Disponível em: < http://meusitejuridico.com.br/2017/11/20/sumula-599-stj-nao-se-aplica-oprincipio-da-insignificancia-nos-crimes-contra-administracao-publica/> . Acesso em: 20 Mai 2018.

DI PIETRO, Maria Sylvia Zanella. Direito Administrativo. São Paulo: Atlas, 2006

DWORKIN, Ronald. Levando os direitos a sério. Tradução de Nelson Boeira. São Paulo: Martins Fontes, 2002.

ESPÍNDOLA, Ruy Samuel. Conceito de Princípios Constitucionais. Revista dos Tribunais, São Paulo, 1999.

GASPARINI, Diógenes. Direito Administrativo. 10. ed. rev. e ampl. São Paulo: Saraiva, 2004.

GOMES, Luiz Flávio. Princípio da Insignificância e outras excludentes de tipicidade. 2 ed. atual. e ampl. São Paulo: Editora Revista dos Tribunais, 
2010.

GRAU, Eros Roberto. A Ordem Econômica na Constituição de 1988 (Interpretação e Crítica). São Paulo: Revista dos Tribunais, 1990.

GRECO, Rogério. Código Penal Comentado. 11ª ed. Niterói: Impetus, 2017. GRECO, Rogério. Curso de direito penal-parte geral. v. I. $12^{\mathrm{a}}$ ed. Niterói: Impetus, 2010.

HUNGRIA, Nelson. Comentários ao Código Penal. V. IX. Rio de Janeiro: Ed. Revista Forense, 1959.

KELSEN, Hans. Teoria pura do direito. 8. ed. São Paulo: WMF; M. Fontes, 2009.

LEAL JÚNIOR, Cândido Alfredo Silva. O princípio da insignificância nos crimes ambientais: a insignificância da insignificância atípica nos crimes contra o meio ambiente da Lei 9.605/98. Revista de Doutrina da $4^{a}$ Região, Porto Alegre, n.17, abr. 2007. Disponível em: <http://www.revistadoutrina.trf4.jus.br/artigos/edicao017/Candido_Leal.ht m>. Acesso em: 26 fev 2018.

LOPES, Mauricio Antonio Ribeiro. Princípio da insignificância no direito penal. 2 ed. São Paulo: Revista dos Tribunais, 2000.

LUISI, Luiz. Os princípios constitucionais penais. 2a ${ }^{\text {a }}$ ed. Porto Alegre: Sérgio Antônio Fabris. 2003.

MAÑAS, Carlos Vico. O princípio da insignificância como excludente da tipicidade no Direito Penal. São Paulo: Saraiva. 1994.

MARINONI, Luiz Guilherme. Precedentes obrigatórios. 4a edição. São Paulo: Revista dos Tribunais, 2016.

MASSON, Cleber. Código Penal Comentado. $2^{a}$ ed. São Paulo, 2014.

MEIRELLES, Hely Lopes. Direito Administrativo Brasileiro. 28. ed. São Paulo, Malheiros, 2003. 
MIRABETE. Julio Fabbrini. Código Penal interpretado. 5. ed. São Paulo: Atlas, 2005.

MIRABETE, Julio Fabrini e FABRINI, Renato N.. Manual De Direito Penal. 24.ed. São Paulo: Editora Atlas S.A., 2010.

NORONHA, Edgard Magalhães. Direito penal. 19. ed. V.4 São Paulo: Saraiva, 1988.

NUCCI, Guilherme de Souza. Código Penal Comentado. $6^{\mathrm{a}}$ ed. São Paulo: RT, 2006.

PAGLIARO, Antônio; COSTA JUNIOR, Paulo José da. Dos crimes contra a administração pública. São Paulo: Malheiros Editores, 1997.

PRADO, Luiz Regis. Curso de Direito Penal Brasileiro. $4^{\mathrm{a}}$ ed. São Paulo: Editora Revista dos Tribunais, 2010.

QUEIROZ, Paulo. Princípio da Insignificância. Disponível em < http://www.pauloqueiroz.net/476/>. Acesso em 22 fev. 2018.

REALE, Miguel. Lições Preliminares de Direito. $27^{\mathrm{a}}$ ed. São Paulo: Saraiva, 2003.

ROCHA, Cármen Lúcia Antunes. Princípios constitucionais da administração pública. Belo Horizonte: Del Rey, 1994.

ROUSSEAU, Jean-Jacques. Do Contrato Social. Tradução de Ricardo Rodrigues da Gama. 1ª ed. São Paulo: Russel, 2006.

SILVA, Ivan Luiz da. Princípio da Insignificância no Direito Penal. 2. ed. Curitiba: Juruá, 2011.

SOUZA, Rogerio Soares de. A jurisprudência como fonte do direito. Disponível em: $<$ http://revista.faculdadeprojecao.edu.br/index.php/Projecao2/article/downl oad/411/368>. Acesso em 22 abril. 2018.

STRECK, Lenio Luiz. Hermenêutica Jurídica e $(m)$ crise. $5^{\text {a }}$ ed., Porto Alegre: Livraria do Advogado, 2004. 
Universidade de São Paulo. Declaração dos Direitos do Homem. Disponível em

$<$ http://www.direitoshumanos.usp.br/index.php/Declara\%C3\%A7\%C3\%A3 o-Universal-dos-Direitos-Humanos/declaracao-universal-dos-direitoshumanos.html >. Acesso em 22 fev. 2018.

ZAFFARONI, Eugenio Raúl. PIERANGELI, José Henrique. Manual de direito penal brasileiro: volume 1: parte geral. $9^{a}$ ed. rev. e atual. São Paulo: Editora Revista dos Tribunais, 2011. 


\section{NORMAS PARA ELABORAÇÃO E APRESENTAÇÃO DA MONOGRAFIA}

\section{ANEXO II}

\section{A Monografia deve ser entregue até o dia 05 de junho de 2018}

A presente Monografia, apresentada pelo (a) aluno (a) Dojenne Davealleo
do Rolha poderá ser submetida à exposição e defesa perante a Banca Examinadora designada pelo Departamento de Direito da PUC-Rio.

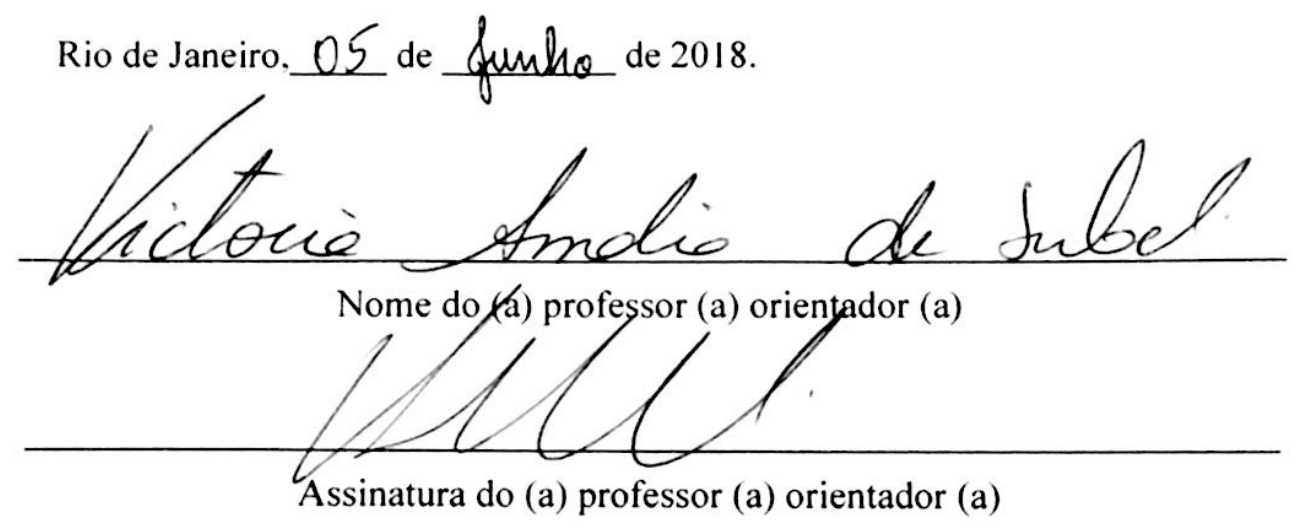

O (A) autor (a) deste trabalho declara para todos os fins de Direito ser este um trabalho inédito e autoriza o Departamento de Direito da PUC-Rio a divulgá-lo, no todo ou em parte, resguardados os direitos autorais conforme legislação vigente.

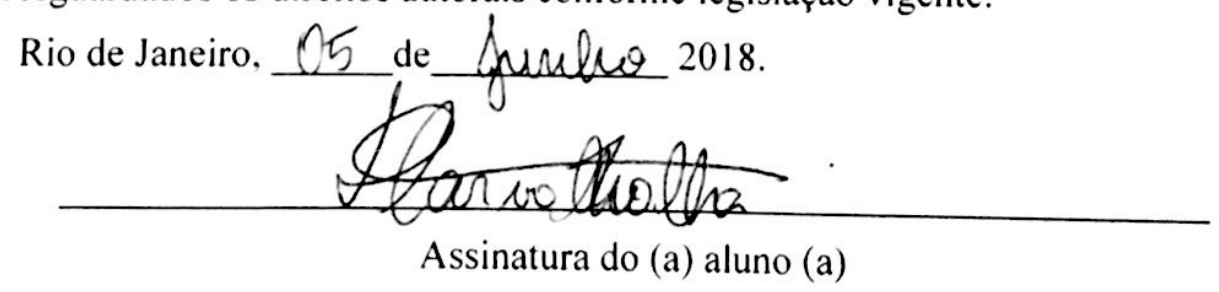

